Portland State University

PDXScholar

\title{
Aboriginal clay figurines from the upper Rogue Valley in southwestern Oregon
}

\author{
Lyman Patrick Deich \\ Portland State University
}

Follow this and additional works at: https://pdxscholar.library.pdx.edu/open_access_etds

Part of the Archaeological Anthropology Commons, and the Ceramic Arts Commons Let us know how access to this document benefits you.

\section{Recommended Citation}

Deich, Lyman Patrick, "Aboriginal clay figurines from the upper Rogue Valley in southwestern Oregon" (1980). Dissertations and Theses. Paper 3263.

https://doi.org/10.15760/etd.3254

This Thesis is brought to you for free and open access. It has been accepted for inclusion in Dissertations and Theses by an authorized administrator of PDXScholar. Please contact us if we can make this document more accessible: pdxscholar@pdx.edu. 
AN ABSTRACT OF THE THESIS OF Lyman Patrick Deich for the Master of Arts in Anthropology presented November 28, 1980.

Title: Aboriginal Clay Figurines From the Upper Rogue Valley in Southwestern Oregon.

APPROVED BY MEMBERS OF THE THESIS COMMITTEE:

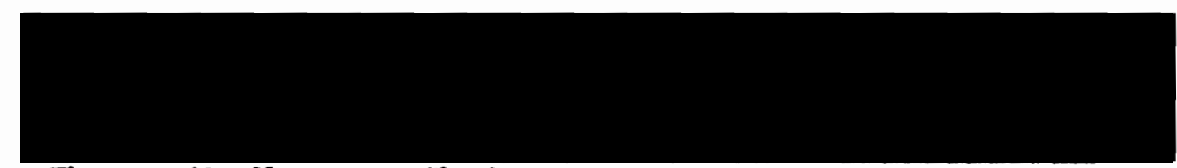

Thomas M. Newman, Chairman

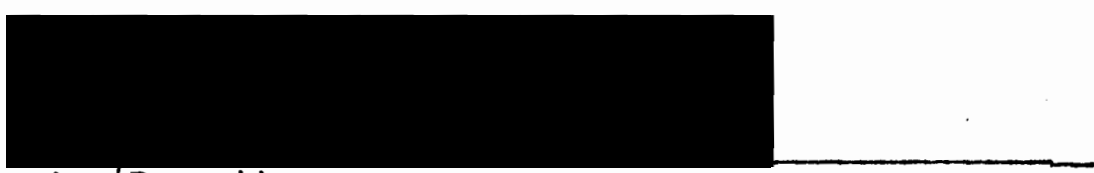

Ann Bennett

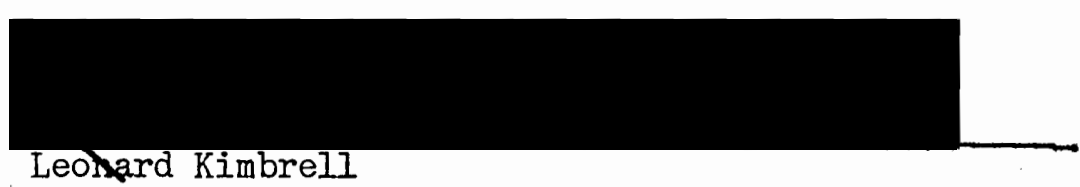

A study of 80 clay figurines from aboriginal sites in the upper Rogue River Valley in southwestern Oregon fails to reveal any connection with other figurines found in the Pacific Northwest and northern Califormia. A preference for animal rather than human representations is demonstrated. The temporal distribution of the figurines is not known, but spatial distribution appears roughly coextensive with territories occupied by the upland Takelma at the time of Euro-American contact during the second quarter of the nineteenth century. 
ABORIGINAL CLAY FIGURINES FROM THE UPPER

ROGUE VALLEY IN SOUTHWESTERN OREGON

by

LYMAN PATRICK DEICH

A thesis submitted in partial fulfillment of the requirements for the degree of

\author{
MASTER OF ARTS \\ in \\ ANTHROPOIOGY
}

Portland State University

1982 
TO THE OFFICE OF GRADUATE STUDIES AND RESEARCH:

The members of the Committee approve the thesis of

Lyman Patrick Deich presented November 28, 1980.

Thomas Newman, Chairman

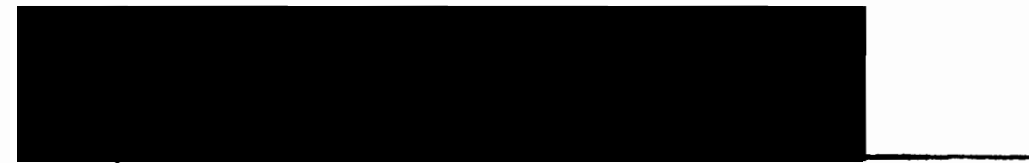

M. Ann Bennett

Leonarả Kimbrell

APPROVED :

Joe E. Pierce, Head, Department of Anthropology

Stanley Rauch, Dean of Graduate Studies and Research 


\section{ACKNOWLEDGEMENTS}

This work would not have been possible without the cooperation of Delmar Smith, Caroline Jensen, Roy Reed and Ray Peery who allowed me to examine their collections repeatedly and who patiently answered my many questions, nor without the aid of my wife, Carole, who prepared the line drawings and typed and edited the final manuscript. Thanks are also due to the members of my thesis committee, Dr. Thomas Newman, Dr. Ann Bennett and Dr. Leonard Kimbrell for their guidance. 
TABLE OF CONTENTS

PAGE

ACKNOWLEDMENTS ................... i i . . . . CHAPTER

I INTRODUCTION ...................... 1

II THE DELMAR SMITH COLLECTION ............ 5

III THE CAROLINE JENSEN COLLECTION . . . . . . . . 12

IV THE ROY REED COLLECTION ............ 18

V THE RAY PEERY COLLECTION . . . . . . . . . . 24

VI NOTES ON ADDITIONAL ROGUE FIGURINES . . . . . . 32

VII EXPERTMENTAL WORK ............... 33

VIII A NOTE ON THE AUTHENTICITY OF THE ROGUE FIGURINES . . 35

IX THE DISTRIBUTION OF ROGUE FTGURINES IN RETATION TO

WHAT IS KNOWN OF ABORIGINAL POPULATION DISTRIBUTIONS • • 37

I INTERPRETATION .............................. 44

XI INVENTION VERSUS DIFHUSION ............. 51

XII USE AND FUNCTION OF THE FTGURINES . . . . . . . 55

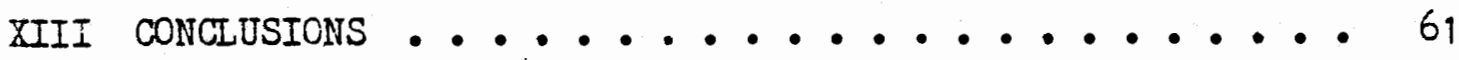

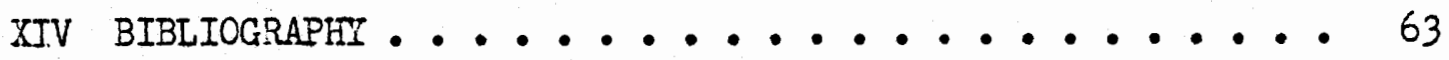




\section{INTRODUCTION}

When I went to southwestern Oregon in November of 1975 as the first archeologist to be employed by the Medford District Office of the U. S. Bureau of Land Management, it soon became apparent that the prehistory of this entire area was very poorly understood. The region had been rapidly overmm by prospectors in the southern Oregon gold rush of 1851, and in 1856, after five years of unremitting hostility marked by two wars and uncounted raids and atrocities perpetrated by both Whites and Indians, the surviving native populations were forcibly removed to a reservation in northwestern Oregon.

Such circumstances did not lend themselves to the collection of accurate and unbiased ethnographic information. Mention of the local Indians in the documents of the period deals largely with their ferocity, perfidy and other imputed vices. It was not until many years later that any professional ethnographic work was done anong the few survivors of native populations. (Dorsey 1884, Sapir 1907, Drucker 1939)

As with ethnogrephy, so with archeology. Farmers had rapidly followed the miners, and by 1854 all of the readily arable land in the Rogue Valley, the very land that had probably been the focus of aboriginel use and occupation, had gone under the plow. (Farnham 1955) Further, gold mining, especially the large-scale hydraulic operations of the 1870's and later, washed away many of the remaining riparian sites as well as most evidence of the miner's own past. 
fact that the preservation of archeological materials, here as elsewhere in western Oregon, is poor. Therefore, professional archeologists cannot be faulted for slighting this area in favor of other parts of North America where research was likely to be more rewarding.

Professional excavation in the area has been rather limited. Cressman excavated a large site near Gold Hill on the Rogue River in the early $1930^{\prime} \mathrm{s}$. Newman did some salvage excavation in 1958 along the upper reaches of Bear Creek Valley at what is now Emigrant Lake. More recently Davis excavated a number of small sites in connection with salvage operations prior to the construction of Lost Creek Dam on the Rogue, and most recently (1978) Brauner did fairly extensive excavation along the Applegate River. This was also a salvage operation. In addition, there have been a number of surface surveys conducted by government agencles prior to various land impacting projects. Generally these have been of a minor and cursory nature.

There is, however, a great deal of material from the Rogue River area in amateur collections. While there had often been a tendency on the part of professional archeologists to condemn these people out of hand as destroyers of sites, it appears that in many instances the materials which comprise the bulk of their collections are those which would have been lost anyway, items plowed up in farmers' fields or unearthed in construction operations on private lands or perhaps taken from public lands before there was any serious attempt to manage archeological resources or enforce the antiquities laws. Onder these circumstances the preservation of these materials with even minimal data that collectors usually obtain is certainly to be preferred to their total loss. 
It appeared to me that one approach to the study of the prehistory of the area lies in the investigation of these many amateur collections, an approach which had already been used in the Umpqua drainage to the north. (Marchiando 1965) Clay figurines were selected for the present study because they had previously gone unreported in the literature from the Rogue, and because the number of available specimens, while large enough to form a basis for some conclusions, was still small enough to be handled in a master's thesis.

The basic and general question to be dealt with here then is the utility and validity of amateur collections in regional archeology. That is, which questions can or cannot be investigated on the basis of this sort of material. More specifically, it was decided to attempt intersite and interareal comparisons of figurines based on the relative frequencies of the types of subject matter represented. This was based upon the following assumptions:

1. Glay figurines, though certainly functional in a Malinowskian sense, are not utilitarian; therefore, their form is not as limited by practical considerations as that of projectile points, for example. Thus, differences could be seen to be besed upon stylistic, as opposed to possibly environmental, factors.

2. Collectors would be able to establish site provenience, even though provenience within the site might be vague.

3. That the samples would be large enough to make supportable general statements regarding figurines from the area and at least three specific sites within the area. 
It developed during the course of my investigations that the second of these assumptions was untrue, leading to a partial negation of the third assumption. While one could almost always accept areal provenience, the specific site of origin was open to question in a fair number of instances. The samples from individual sites were small enough that the invalidation of any of the material would have seriously affected the conclusions.

On the other hand, the general area of origin was never in question, and the total sample was large enough that the subsequent invalidation of a few items would not appreciably affect one's overall conclusions. Therefore, it will be shown that the study of amateur collections is a worthwhile approach to the prehistory of the area, but It will not support the type of studies initially envisioned. Beyond this, we may ask:

1. Who made the figurines? Can they be tied to any group of people known to exist in a specific area at a certain time?

2. How did they come to be made? Was the notion of molding clay into human and animal figurines and then placing these objects into a fire whereby they gained permanence, a local invention, or did it arrive from somewhere else?

3. Can the figurines themselves, and such limited data as is available regarding their recovery, give us any clue as to how they might, or mighi not, have been functioning in the cultural system which produced them?

As is not uncommon, the study has raised more questions than it has answered, but considering the limited state of our present knowledge, this is as it should be. 


\section{THE DELMAR SMITH COLLECTION}

The figurines in this collection are on display in Mr. Smith's private museum in Central Point, Oregon. They were originally collected by Treavell Turpin of Medford, Cregon, some of them as long ago as 1950. Both men say most of the figurines ceme from the nearby Snider Creek site. A few are from trail Creek, but Mr. Turpin is not certain as to which ones. Mr. Turpin stated the items were often found in back dirt after rain. (Turpin 1979) The collection is uncatalogued, and the numbers given here are for our convenience only. Since the figurines have been gIued to a styrofoam board, some difficulty was encountered in obtaining good photographs and drawings. Presentiy (1979) Mr. Smith is arranging for the transfer of his collection to the Jacksonville Museum; thus these pieces will be catalogued and available for study. All of the drawings below are actual size.

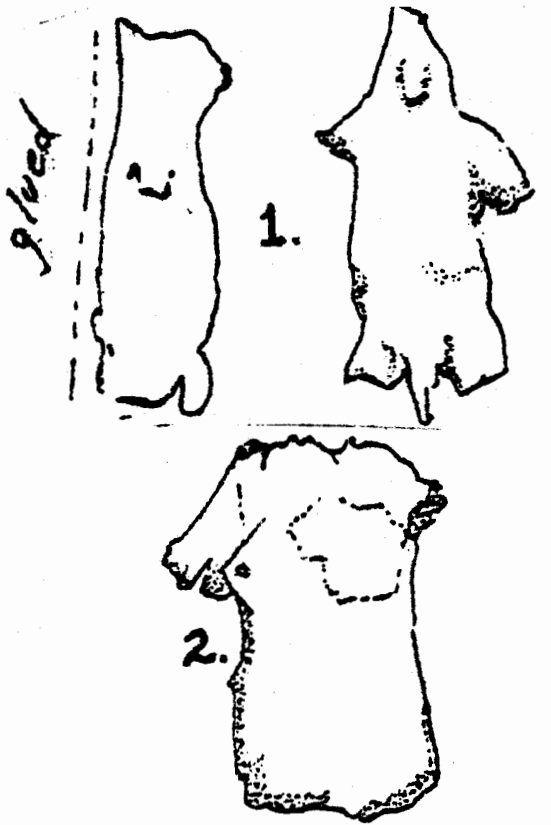

1. Human male figurine $41 \mathrm{~mm}$. in length by $12 \mathrm{~mm}$. in diameter. The sex is indicated by a clearly formed penis; the eyes, mouth and other facial features are not indicated. The legs appear to have been broken off. Color is reddish brown (5YR $5 / 3)$

2. Human female torso. The head, lower extremities and left breast are broken away. The right nipple has been indi- 


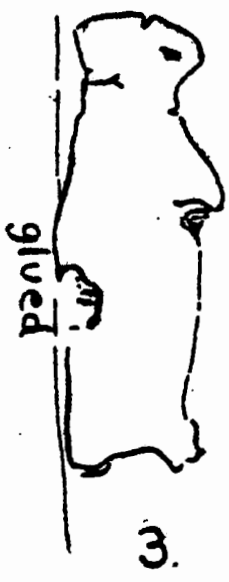

cated by a small indentation. The breasts appear to have been formed as spherical appliques, Overall length of the fragment is $35 \mathrm{~mm}$. It is $18 \mathrm{~mm}$. wide by $14 \mathrm{~mm}$. thick. The color is light reddish brown (5YR $6 / 3)$.

3. Human male figurine, the sex again being indicated by the penis. Eyes are indicated by small indentations. The right lat,eral aspect of the figurine is illustrated here. A small hole can be seen entering the lower dorsal region. The overall length is $37 \mathrm{~mm}$. Maximum width and depth are each about $14 \mathrm{~mm}$. Color is dark reddish gray ( $5 \mathrm{YR} 4 / 2$ ).

4. Human figurine without primary sexual characteristics. An ellipse formed by eight puncture marks probably indicates a necklace, and below this are three vertical indentations which seem to indicate a pendant. The head is entire but is merely an expanded knob with no features indicated. The piece is 

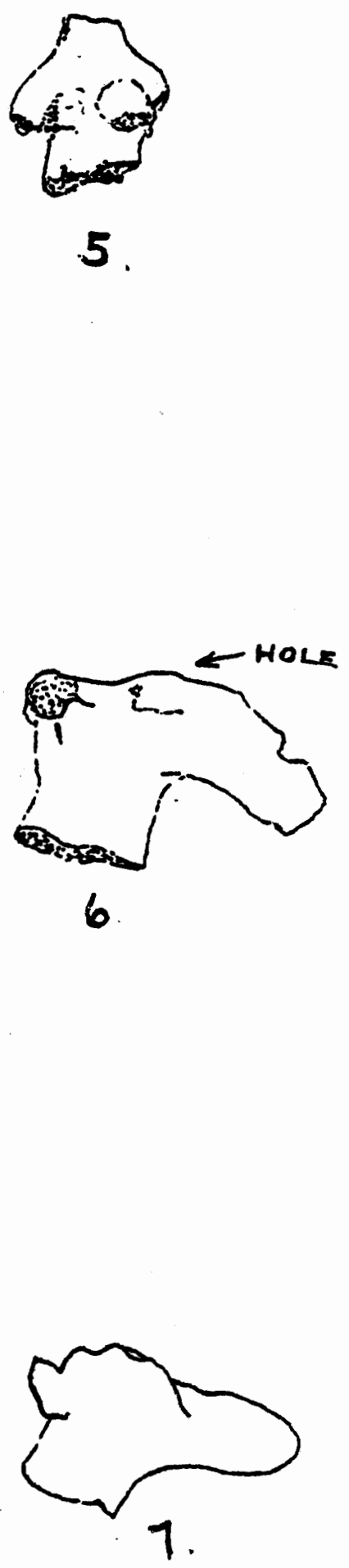

fractured at the base. It is $28 \mathrm{~mm}$. long by $19 \mathrm{~mm}$. wide and $14 \mathrm{~mm}$. deep. color is weak red $(2.5 \mathrm{YR} 5 / 2)$.

5. Human female torso. The fragment is $18 \mathrm{~mm}$. in length by $17 \mathrm{~mm}$. wide and $13 \mathrm{~mm}$. deep. Both the head and lower portions are missing as is the right breast. On macroscopic examination at least, the left breast does not appear to be an applique. There is no indication of a nipple. Color is weak red (2.5YR $5 / 2)$.

6. Animal head. Apparently that of one of the cervidae and could most reasonably be seen as that of an elk. The eyes are raised, and it may have had antlers which were broken off at their bases. There is a hole penetrating superiorly into the mid-frontal region. It is $37 \mathrm{~mm}$. from nose to antler base, and the muzzle is about $11 \mathrm{~mm}$. in diameter. Color is weak red (2.5YR $5 / 2)$.

7. Cervid-like head with a slight bit more of the antler remaining than 


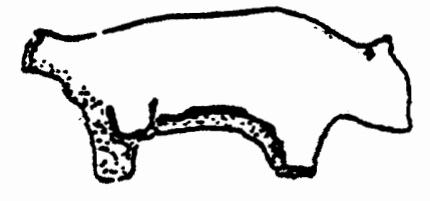

8
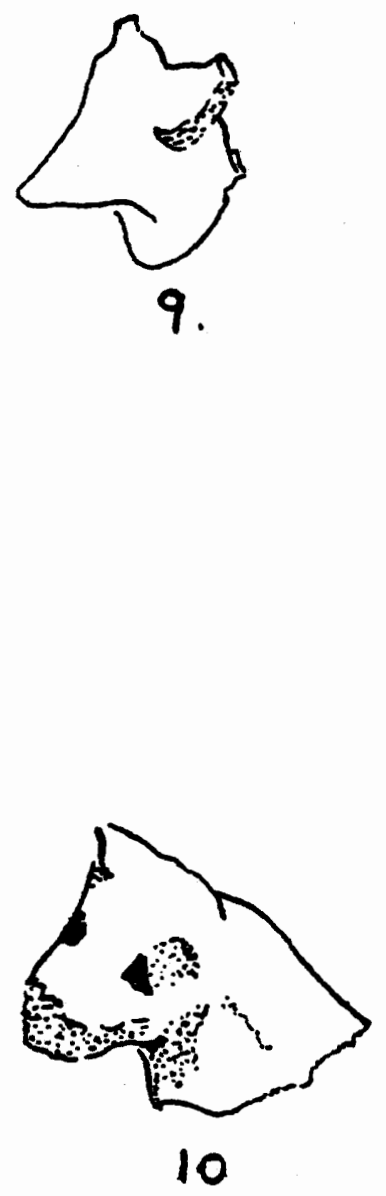

is seen in number six above. The eyes are not indicated. The head is $32 \mathrm{~mm}$. Iong by $9 \mathrm{~mm}$. diameter at the mid-portion. Color is dusky $\operatorname{red}(2.5 \mathrm{YR} 2 / 2)$

8. Quadruped. Entire except for the tail. The ears are indicated. The eyes are not indicated, but the supraorbital ridges are shown. It almost certainly represents a squirrel. It is $36 \mathrm{~mm}$. Iong and $10 \mathrm{~mm}$. in diameter. Color is pinkish gray (5YR 6/2)

9. Cervid-like head. The antlers are broken; no other features are shown. length is $20 \mathrm{~mm}$. Basal diameter is about $10 \mathrm{~mm}$. Color is a very dark gray (5YR $3 / 1)$

10. Canid or possibly ursid head with a blunt muzzle, clearly indented eyes and upraised ears. It is remarkable in that the neak is turned somewhat to the right to give a much more naturalistic appearance. In all of the other animal heads observed, the head and neck have been in the same plane. The greatest. 
dimension is about $34 \mathrm{~mm}$. with a midmiameter of $18 \mathrm{~mm}$. Color is light reddish brown (5YR 6/3).

11. Small cervid-like head with raised eyes and a broken protuberance corresponding to the area which would be the base of the antlers. Length from nose to back of head is $22 \mathrm{~mm}$; diameter of neck at base of head is $10 \mathrm{~mm}$. Color is reddish brown (5IR 4/3).

12. Animal head of undetermined species,

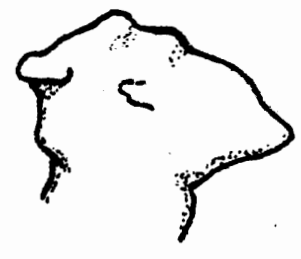

12

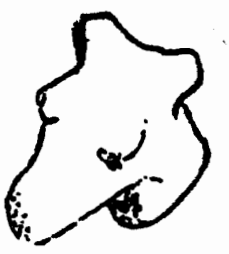

13 although the overall configuration

is vaguely ovine. The eyes are riased and the ears are short. It is shown here in a three-quarter view. In direct frontal view, it is strongly triangular, and the eyes face more forwardly than laterally. The head is $26 \mathrm{~mm}$. long by $15 \mathrm{~mm}$. broad at the top. Neck diemeter is $13 \mathrm{~mm}$. Color is reddish gray (5YR 5/2).

13. Small cervid head with raised eyes. The head is $21 \mathrm{~mm}$. in length, and neck diameter is $9 \mathrm{~mm}$. Color is dark gray (5YR 4/1). 


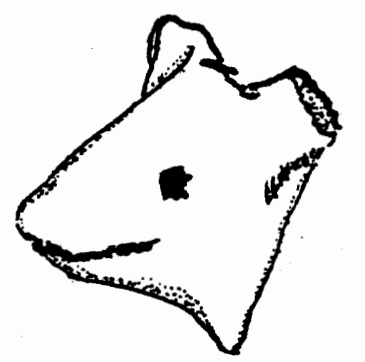

14.

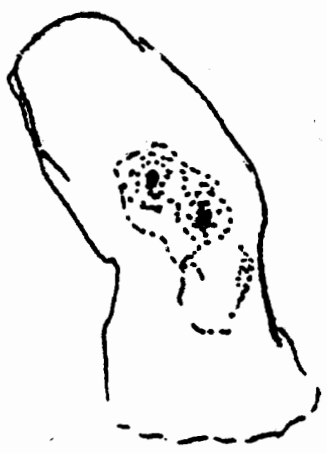

15

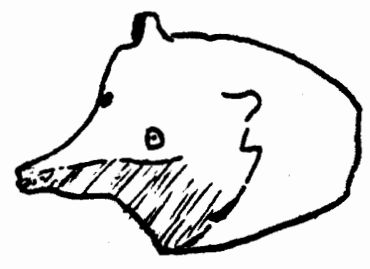

16

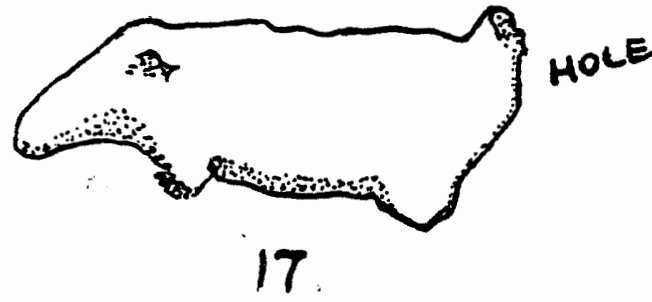

14. This head is very rat-like, possibly representing Neotoma. The ears have been broken, but the bases show them to have been broad. The eyes are strong indentations, and the mouth is indicated by a raised line. The head is $26 \mathrm{~mm}$. long by $19 \mathrm{~mm}$. broad. Color is gray (5YR 5/1).

15. Apparent attempt at an animal head. There is an area on one side where something-possibly an appliquehas become detached. Length is 44 mm.; diameter is about $17 \mathrm{~mm}$. Color is light reddish brown (5YR 6/3).

16. This head has a fox-like or wolflike appearance. The snout is very narrow. The eyes appear as small shallow holes, and the ears are small but distinct, and there appears to be a ruff outlining the face. The fragment is $33 \mathrm{~mm}$. in length and the diameter at the ruff about $18 \mathrm{~mm}$. Color is reddish brown $(5 \mathrm{YR} 5 / 3)$.

17. Entire quadruped. The tip of the upturned tail-has been fractured. 
There is a hole in the anal region. The limbs are short but entire and clearly indicated. There is a slight protuberance at each ear. The eyes are not indicated. Maximum length is about $50 \mathrm{~mm}$; depth 16 mm.; width $12 \mathrm{~mm}$. Color is a reddish gray (5YR 5/2).

18. On the display board, this was placed next to, and in alignment

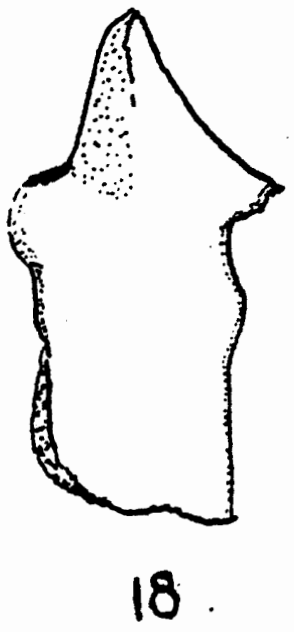
with, number 17 above, giving one the impression that it was intended to be another quadruped with the rear extremities missing. However, the protuberance shown on the upper left in the drawing is clearly single, not double. The upper portion is laterally compressed, and the vertical line appears to have been accidental. This almost certainly was intended as a human figurine but was either very poorly executed or abandoned before completion. The length is $51 \mathrm{~mm}$, width $20 \mathrm{~mm}$. and thickness about $14 \mathrm{~mm}$. Color is gray (5YR 5/1). 
THE CAROLINE JENSEN COLLECTION

These figurines in the possession of Caroline Jensen of Central Point, Oregon, were collected by her late husband Charles. They were taken both from the Snider Creek site and from another site on Trail Creek one or two miles above its confluence with the Rogue. Many were collected as long ago as 1939.

These items, like those in the Delmar Smith Collection, have been mounted on a styrofoam board, and have been placed in a sealed box with a non-removable glass front. This renders adequate drawings or photography nearly impossible. The dravings show only the more sailent features, and except for \#9, are about actual size. No measurements were attempted.
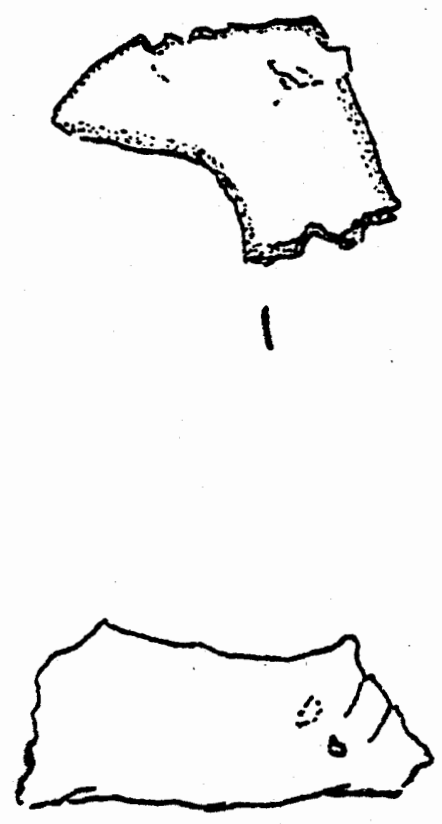

2
1. Cervid-like head. A broken area over the eye indicates it may have had protuberent appliqued eyes.

2. Animal head. I wouldn't hazard a guess as to the animal intended. The ears are quite short. The eyes are small indentations. There are two horizontal lines on the forehead. The fracture at the base of the neck indicates it may have been part of a complete representation.

3. Larger cervid-appearing head, possibly 


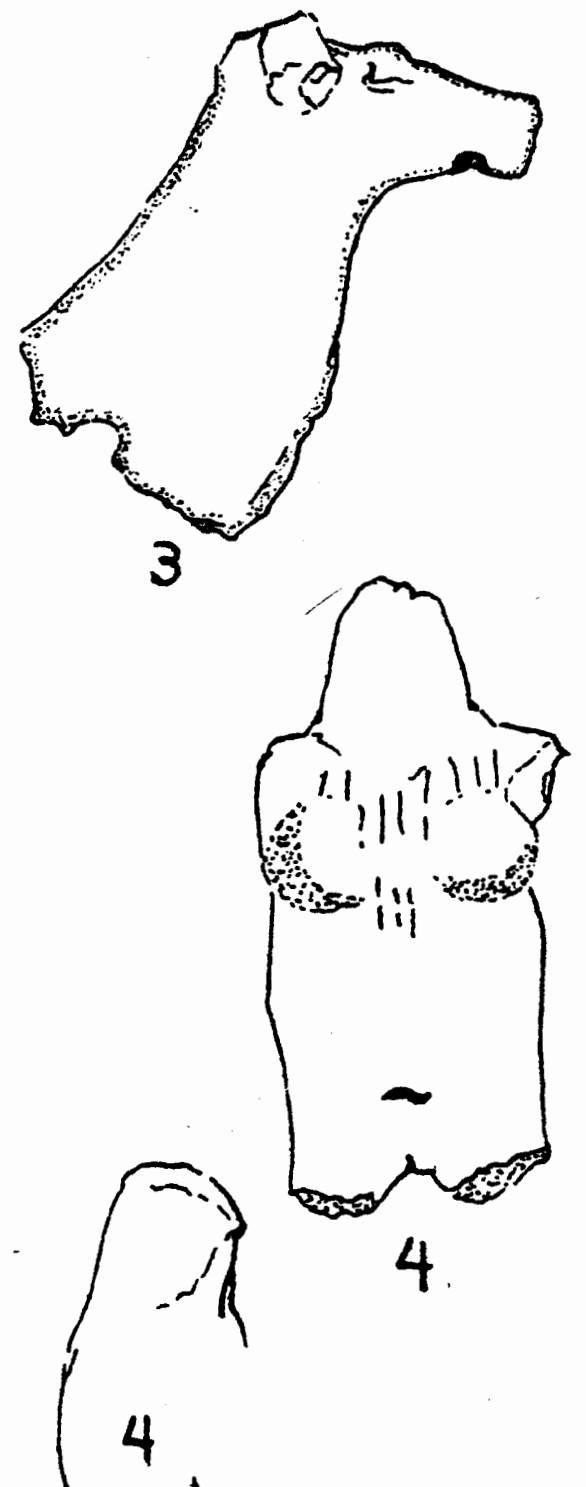

Head
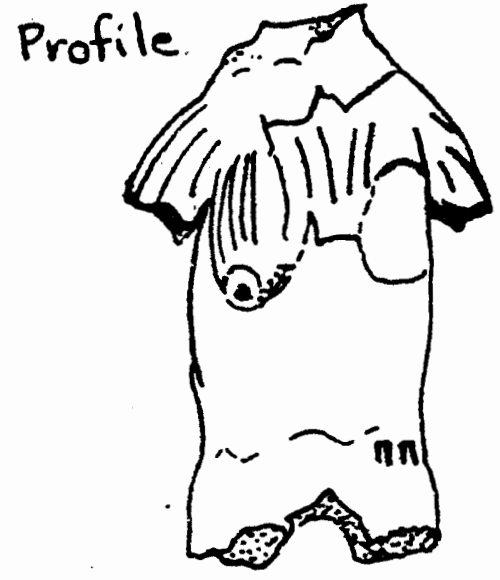

5 that of an elk. It has the protuberant eyes, but it cannot be ascertained if these are appliques. There is a broken area corresponding to the base of the antlers. A single horizontal line across the muzzle appears to indicate the mouth. The notch on the lower jaw appears to be a deliberate impression. 4. Obviousiy human female representation. The figurine is entire. The lower limbs are merely hinted. The small fissure on the lower abdomen appears to be a defect rather than an attempt to portray the umbilicus. There has been no attempt to represent the vulva. No facial features are shown. There is a series of light vertical lines decorating the upper dorso. The breasts are quite clearly appliques.

5. Human female figurine. It is noteworthy in that the remaining breast is quite pendulous, and the nipple is indicated by a circle with a small central depression. The juncture between the breast and the body is not at all apparent. However, the circular area on the left would indicate that the 
breasts were in fact appliques, as this is smooth rather than roughly fractured. The lower extremities are entire. Again there has been no attempt to indicate the vulva. A few vertical marks on the lower abdomen may have indicated a skirt or fringe. The frontal part of the lower abdominal area has spalled off. This decoration of the lower abdomen is similar to that seen in \#2 of the Roy Reed collection. The head is missing.

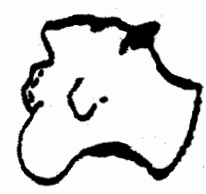

7
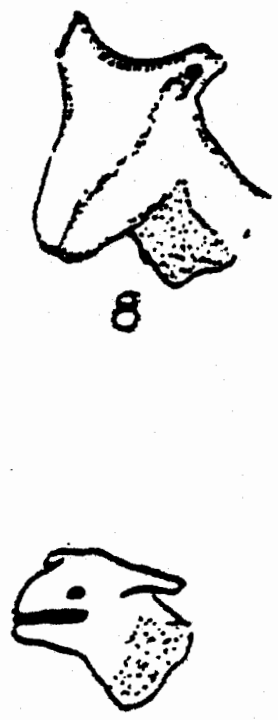

9
6. This rather crude figurine, broken at the base, is probably a human representom tion. It appears to have been mounted face down.

7. Very small cervid-like head. It appears entire with no fractured area at the base of the neck.

8. Cervid-Iike head.

9. Very small animal beac. The drawing is about twice actual size. The mouth is indicated by a deep transverse slot, and the eyes are small indentations. The ears were indicated but the right ear has been broken off at the bese. A larger portion of the left ear remains. 
10. Animal figurine. It is entire except for the tip of the tail. The ears and

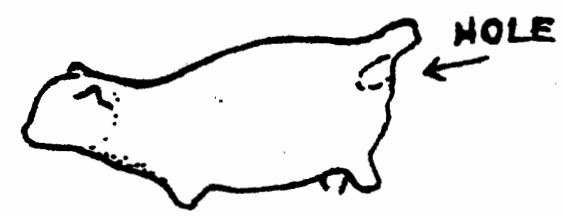

10
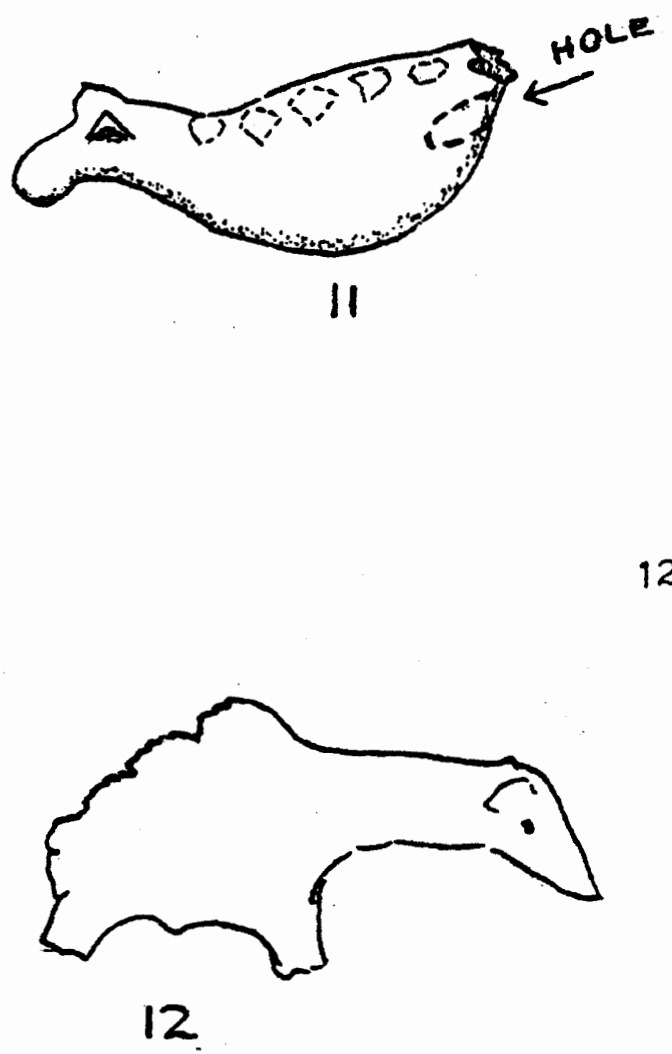

legs are quite short. The eyes are indicated by tiny pinprick-like indentam tions. There is a hole in the anal region. It could be a squirrel, but lacks the obviously sciurid appearance of \#8 in the Delmar Smith collection. It appears quite well finished.

11. This animal figurine is entire except for a small area of fracture at the tail. There is no indication of limbs. The ears are shown but not the mouth or eyes. A hole is again present in what would correspond to the anus. There is a row of five shallow notches dors-laterally on either side. I have no idea as to what is represented here.

12. This curious animal figurine is referred to by Mrs. Jensen as a dinosaur. Another viewer identified it as an anteater. Problems of time in one case and distance in the other would rencer either of these identifications somewhat dubious at best. The figurine seems to have been executed with too much skill to be passed off as an abor- 


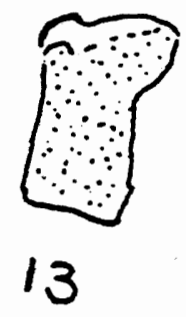

tive and unrecognizable attempt to represent some familiar local animal. It could be a deliberate attempt to stylize and exaggerate some features of a creature such as a wolverine, or it may represent a fanciful creature. The posterior-dorsal portion has been lost, but there is a hole extending forward

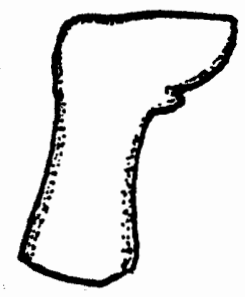

14 into the body.

13. Small animal head. It is possibly cervid, although the resemblance is not as clear as in most.

14. Cervid-like head. It has no detailing except for a small notch indicating the mouth.

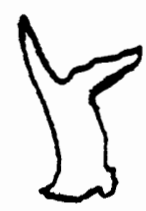

15

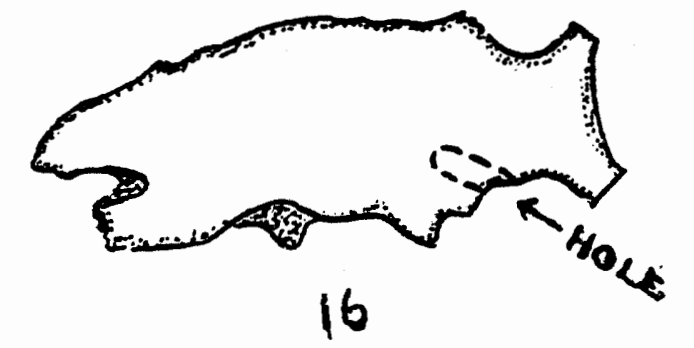

16. Fish; very probably a salmon. The overall appeaiance is rather rough and 
crude, but paired anal and pectoral fins are clearly noted. There is a

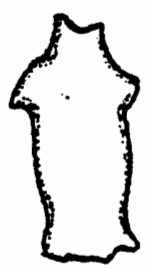

17

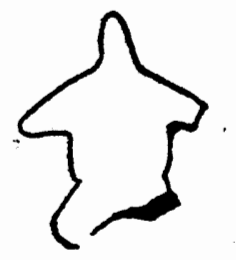

18 hole in the ventral region. The tip of the lower jaw and the tips of the tail are broken. There is no indication of eyes or gills.

17. Tiny human figurine. The base is entire, but the head is broken. There is no decoration and no indication of sex.

18. The collector refers to this piece as a turtle, but it is almost certainly a very stylized human figurine. The arms are notably longer than those seen in other such figurines. The tip of the left arm and the left leg are broken. There are no features, no decorations and no indications of sex. 
THE ROY REED COLLECTION

Those figurines in the collection of Roy Reed of Medford, Oregon, were taken from Snider Creek. This collection also contains a number of cornuate fragments, broken figurines too fragmentary to identify and many sherds of crude pottery. The items are not catalogued, so numbers assigned here are for our convenience only.

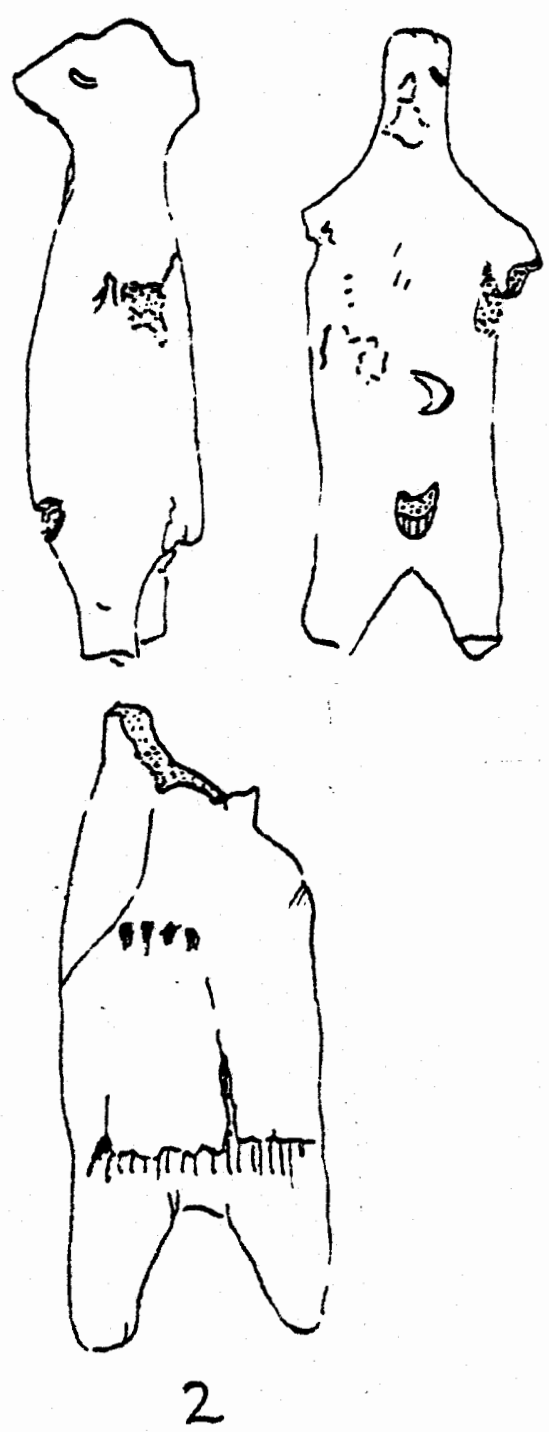

1. Human figurine $60 \mathrm{~mm}$. in height and about $16 \mathrm{~mm} . \times 16 \mathrm{~mm}$. in diameter. The eyes are indicated by indentations. There is a hole in the ventral region. The sex is not indicated. color is brown (7.5YR 5/2).

2. Human figurine $58 \mathrm{~mm}$. in length by 14 mm. thick by $22 \mathrm{~mm}$. wide and is brown in color (7.5YR 5/2). It was recovered in fragments and repaired by the collector; the head wasn't recovered. There's a fringe across the lower abdomen, apparently indicating a garment. There is no hole to indicate the figure was ever mounted; sex is not indicated, at least by any convention the writer can interpret, although the garment itself could have been a 


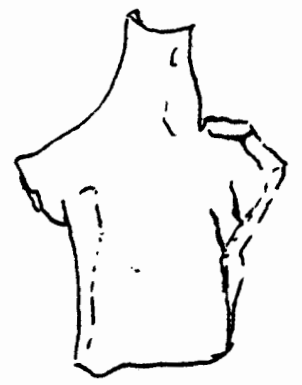

3

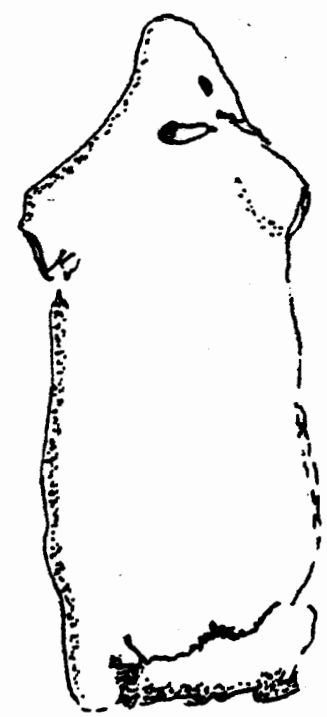

4

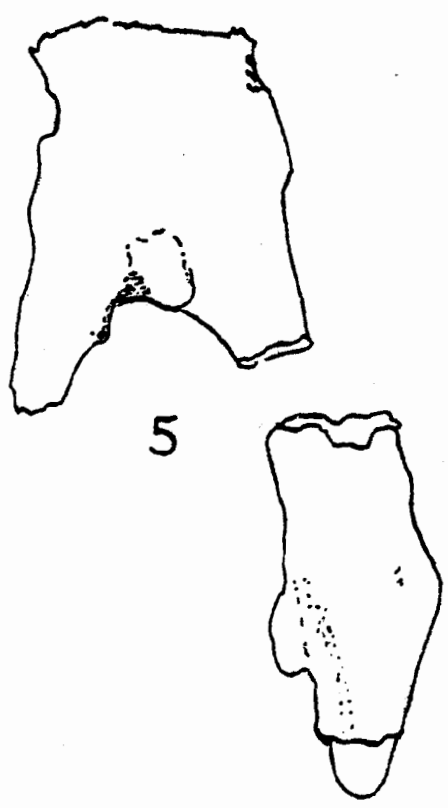

sex indicator

3. Human torso. The head is not entirely intact. Basally there is a hole which could have served to mound the object on a stick. It measures $34 \mathrm{~mm}$. by 14 m. by $24 \mathrm{~mm}$. There is no indication of sex. It is light reddish brown (5YR $6 / 4)$.

4. This figurine is seen as probably human, although it is a very stylized representation. It is the largest figurine in the collection, measuring 65 mm. by $20 \mathrm{~mm}$. deep and $27 \mathrm{~mm}$. wide and is light reddish brown. The object is entire, and there is a hole in the base indicating it may have been mounted on a stick. There is possibly a fringe over the lower abdomen, but this is not at all distinct. There is no indication of sex. Color is $5 Y R 6 / 3$.

5. Lower portion of a male torso. The sex is apparent from the attempt to indicate male genitalia with a burge in the groin. This appears to be raised from the main body of the clay rather than an applique. It is also noteworthy that the buttocks have been rounded to 

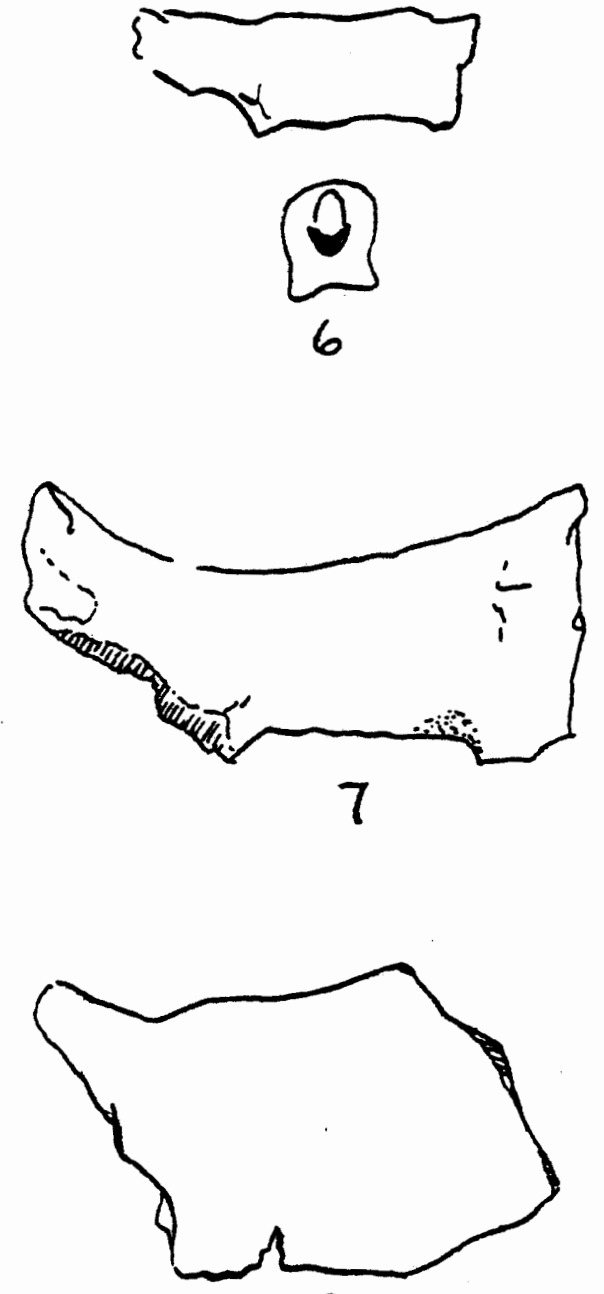

8

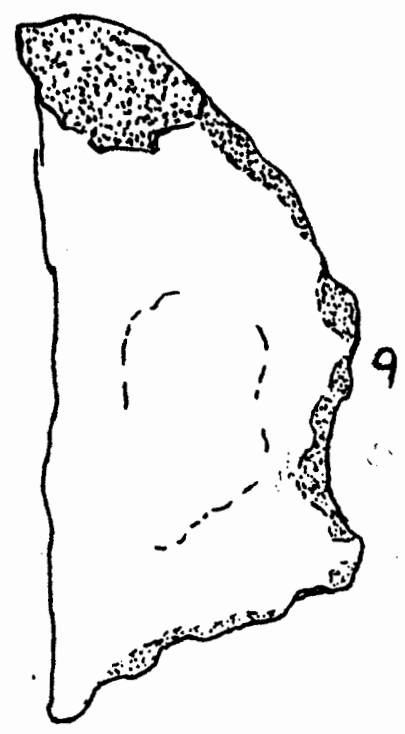

give a more naturalistic appearance. The object measures $40 \mathrm{~mm}$. in height, about one-half that in breadth and some $10 \mathrm{~mm}$. antero-posteriorly. Color is reddish brown (5YR 5/3).

6. Small animal figurine. The head has been broken off. There is a hole at the rear indicating it may have been mounted on a stick. It is $32 \mathrm{~mm}$. in length and $9 \mathrm{~mm}$. in its greatest diam meter by $8 \mathrm{~mm}$. deep. It is reddish gray (5YR 5/2).

7. Animal figurine. Somewhat like \#6 above, but larger, with a length of 54 mm., a depth of $20 \mathrm{~mm}$. and a width of $18 \mathrm{~mm}$. Color is dark reddish gray (5YR 4/2). The head is also missing, and there is a hole in the anal region.

8. Posterior portion of a figurine similar in most respects to the two preceding, but larger still, the extant portion being some $40 \mathrm{~mm}$. in length by $18 \mathrm{~mm}$. laterally and $26 \mathrm{~mm}$. deep. The hole in the anal region is again noted. Color is reddish gray ( $5 Y R$ 5/2).

9. Crude representation of a quadruped with a hole in the anal region. The 


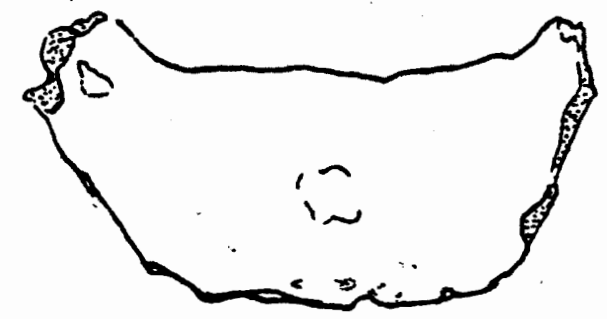

10
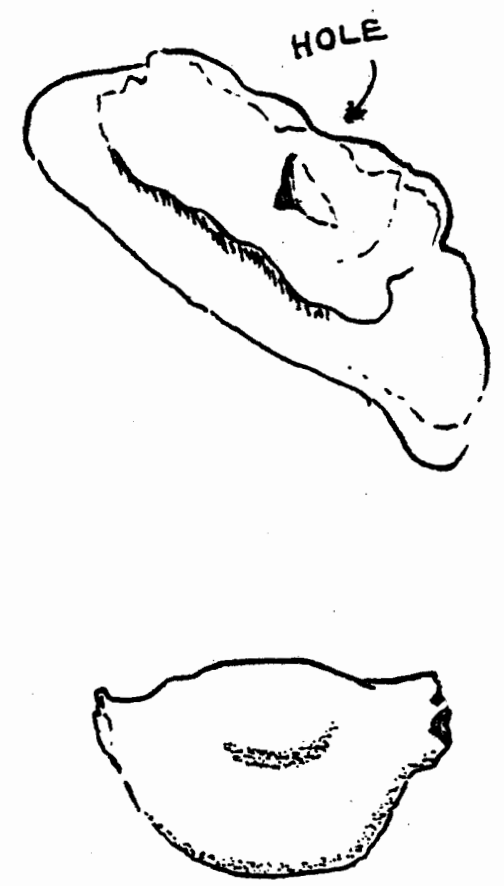

11

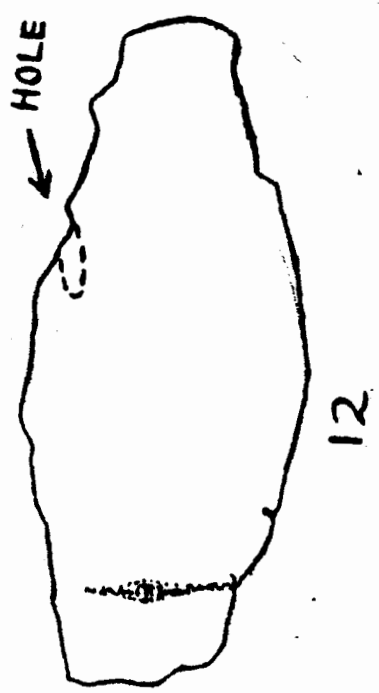

head has been broken off. It measures $65 \mathrm{~mm}$. by $25 \mathrm{~mm}$. by $22 \mathrm{~mm}$. Color is reddish gray ( $5 Y R 5 / 2$ ).

10. What may be represented here is conjea tural. It could possibly be interpreted as a slug, as there appears to be an attempt to depict a gastropod sort of foot rather than lower extremities. There is a hole in the base of the foot. It measures $51 \mathrm{~mm}$. by $17 \mathrm{~mm}$. by $22 \mathrm{~mm}$. The head is not intact. Color is a light brown (7.5YR 6/4).

11. This figurine is most definitely a bird. Unfortunately, the head is missing. The alar margins are raised and rounded, and the tail is clearly indicated. There has been no attempt to depict the feet. The piece is smoothly finished and more symmetrical than most. It is $33 \mathrm{~mm}$. Iong by $19 \mathrm{~mm}$. laterally and 21 mm. deep. There is no hole. The color is dark reddish gray ( $5 Y R$ 4/2).

12. Fish. Gills, paired anal and pectoral fins as well as two dorsal finds are slightly, but nonetheless distinctly, indicated. There is a hole immediately aft the anterior dorsal fin. The figu- 

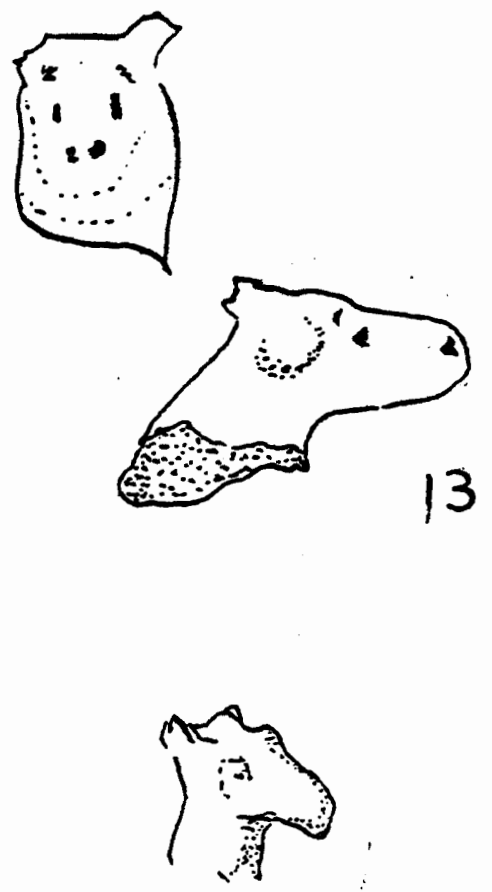

14

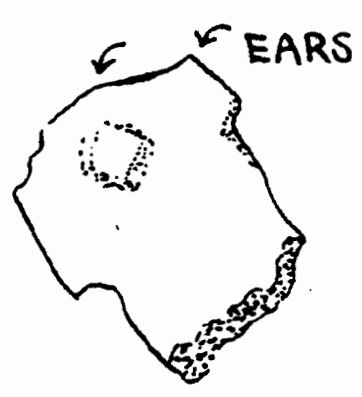

15

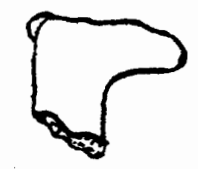

16 rine is entire and is $61 \mathrm{~mm}$. long, 11

mm. wide and $25 \mathrm{~mm}$. deep. Color is

reddish brown ( $5 \mathrm{YR} 5 / 3$ ).

13. Small animal head. Both eyes and nostrils are shown by indentations. It is $32 \mathrm{~mm}$. in overall length with a diameter of about $15 \mathrm{~mm}$. in its largest portion. There are broken ended cylindrical protuberances on the top which may indicate antlers. Color is light reddish brown (5YR 6/4).

14. Small animal head $20 \mathrm{~mm}$. by $10 \mathrm{~mm}$. by $7 \mathrm{~mm}$. Like that preceding, it may have once borne antlers. It differs from the preceding sample in that the eyes are indicated by a raised area rather than indentations. Color is reddish yellow $(5 Y R 6 / 6)$.

15. Portion of an animal head. The muzzle has been lost. It is relatively large, measuring $30 \mathrm{~mm}$. by $25 \mathrm{~mm}$. by $20 \mathrm{~mm}$. The eyes are not indicated, but there are earlike protuberances. Color is black 5 YR 2.5/2).

16. Very small animal head, only $17 \mathrm{~mm}$. in length by 8 to $9 \mathrm{~mm}$. in diameter. Eyes and other features are not shown. 


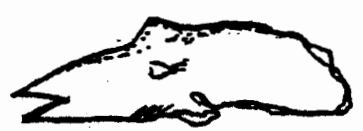

17

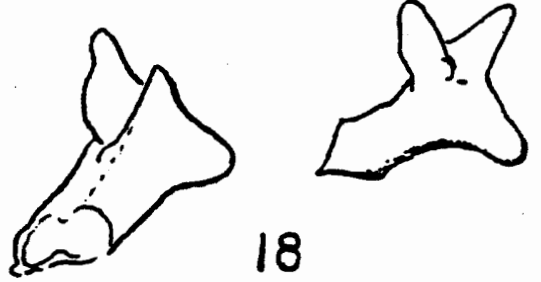

Color is reddish brown ( $5 \mathrm{YR} 4 / 4)$.

17. Animal head. It differs considerably from those preceding. The eyes are slightly raised and the open mouth indicated by a slot. The appearance is rather serpent-like. Dimensions are 32 mm. by $10 \mathrm{~mm}$. by $8 \mathrm{~mm}$. Color is reddish brown (5IR 5/3).

18. Probably the head of a doe. It is 20 mm. in overall length and is very smootinly and delicately finished. The diameter of the neck is approximately $8 \mathrm{~mm}$. Color is reddish brown (5YR $4 / 3$ ). 


\section{THE RAY PEERY COLIECTION}

Mr. Ray Peery of Roseburg, Oregon, has the largest collection of clay figurines I have observed. His collection also contains several hundred fragments of crude pottery representing several distinct types of decoration. Only figurines which are well enough formed to permit identification are presented here. There are at least as many more items which were probably intended as figurines but are too poorly formed or too fragmentary to permit even a reasonable guess as to what is represented. All of these materials were taken from Snider Creek.

None of these items have been catalogued. Fortunately they have never been mounted on display boards. Mr. Peery coated some of them with shellac believing this would be necessary to preserve them. The numbers given here are for convenience only; all dravings are actual size.

1. This is easily recognizable as a feline head, most likely that of a mountain lion. It is very well detailed consid-

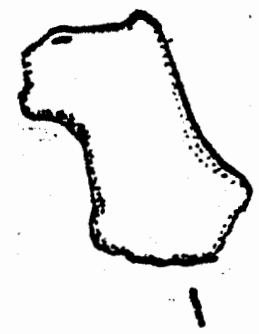
ering its very small size of about 25 mm. by $9 \mathrm{~mm}$. by $9 \mathrm{~mm}$. The ears seem to have been pinched out from the mass of the head. The brow ridges are shown, and the eyes formed under them as slit- Iike indentations. There is a fracture at the base of the neck, indicating the object may have been part of a more com- 

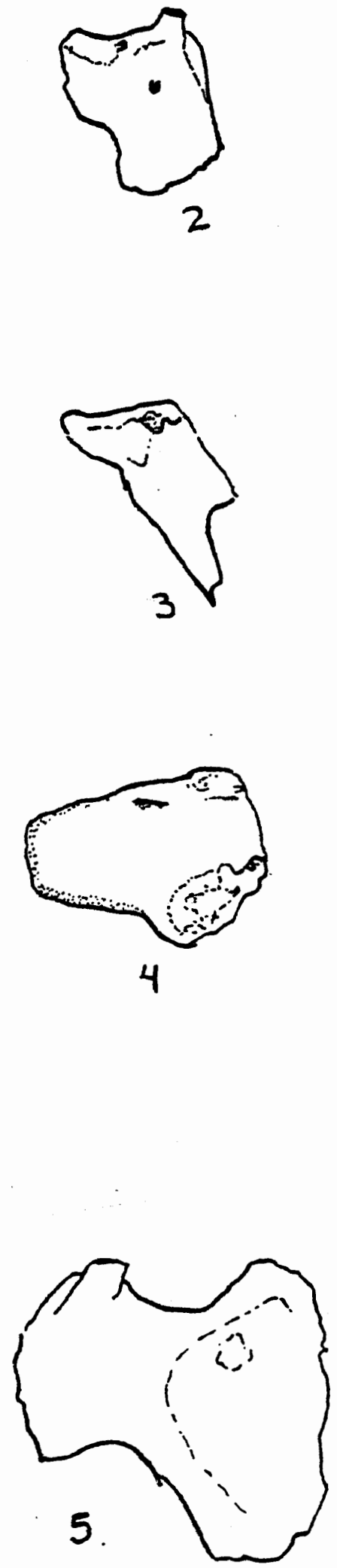

plete figurine. Color is yellowish brown (10YR 5/6).

2. Animal head. Possibly canid, but the muzzle is broken. Dimensions are 13 m. $\times 14 \mathrm{~mm} \cdot \times 21 \mathrm{~mm}$. Color is dark brown (10YR 3/3).

3. This piece is very crude but may represent a canid head. It measures 23 mm. $\times 11 \mathrm{~mm}$. $\times 10 \mathrm{~mm}$. and is yellowish brown (10YR 5/6).

4. Animal head. The broken area that would correspond to the base of the antlers would indicate it to be a cervid representation. However, it is more laterally compressed than most deer and elk heads seen, and it lacks the protuberant eye appliques. It is $32 \mathrm{~mm} \cdot \mathrm{x}$ $22 \mathrm{~mm}$. $x 12 \mathrm{~mm}$. and pale brown in color (10YR 6/3).

5. This is an item of particular interest. When I first saw it, neither I nor Mr. Peery had any idea as to what it might have been. But when compared with \#6 illustrated below, it becomes apparent that it was originally formed as a cervid head. It was damaged while still plastic, probably by being stepped upon. 


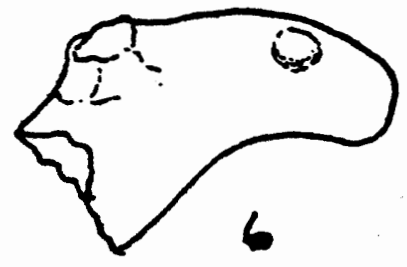

The depression in the right side of the face corresponds well to the impression that might have been made by a big toe, although I have not been able to discern ridges in the imprint. The spherical eye applique can be clearly seen in the depression. It is $42 \mathrm{~mm}$. long by $20 \mathrm{~mm}$. deep and $13 \mathrm{~mm}$. wide. Color is brown (7.5YR 5/4). The reverse side appears to have been compressed against a rough surface.

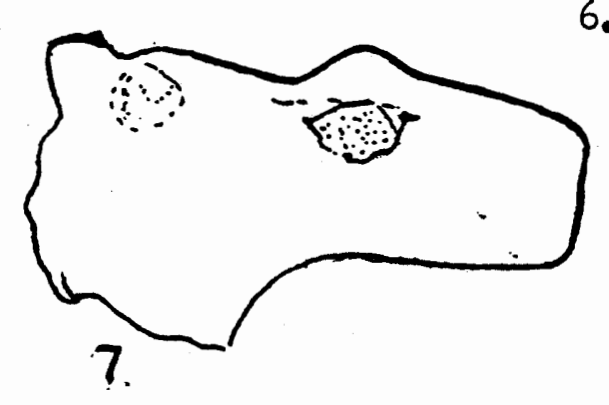

6. Cervid-like head with spherical eye appliques and a fractured area corresponding to the antler base. It is $25 \mathrm{~mm}$. by $15 \mathrm{~mm}$. by $14 \mathrm{~mm}$. and dark brown (10Y R 2/2).

7. Large rather crude cervid-like head, again with the spherical eye appliques.

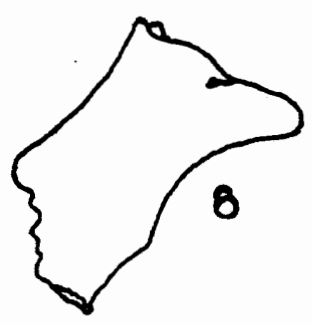

It is $55 \mathrm{~mm}$ by $20 \mathrm{~mm}$. by $17 \mathrm{~mm}$. and brown in color (7.5YR 5/2).

8. Rather crudely made animal head with a somewhat canid appearance. It is $28 \mathrm{~mm}$. by $13 \mathrm{~mm}$. by $13 \mathrm{~mm}$. and dark yellowish

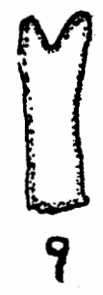
brown (10YR 3/4).

9. This bifurcated fragment may very well be an antler. It is $19 \mathrm{~mm}$. long and 5 mm. in diameter. Color is a dark 

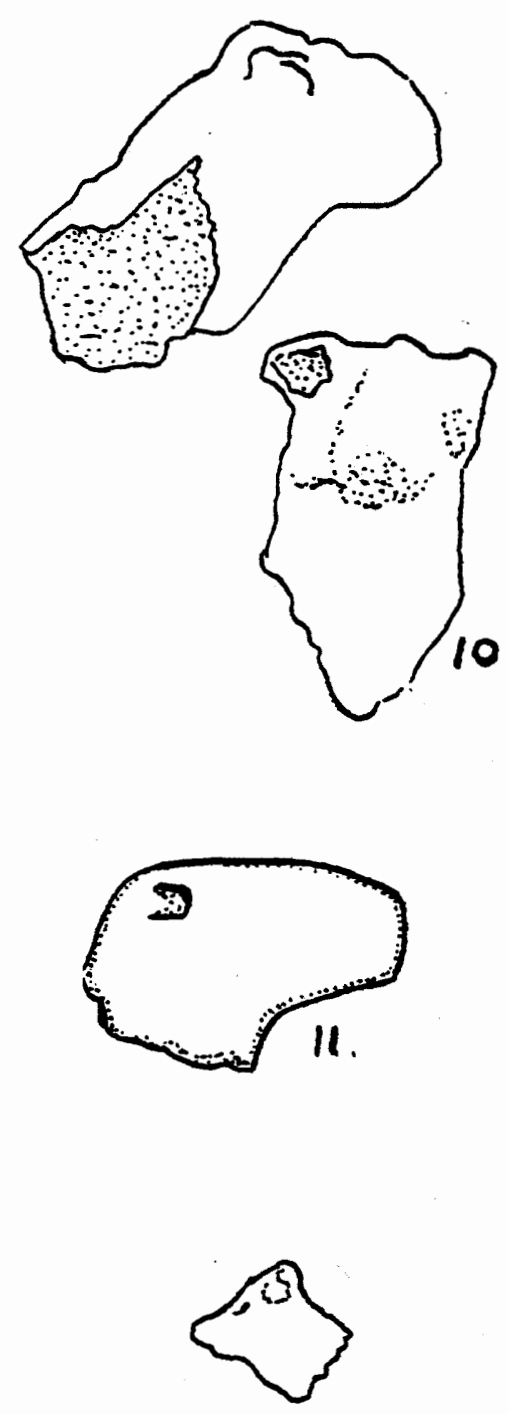

12

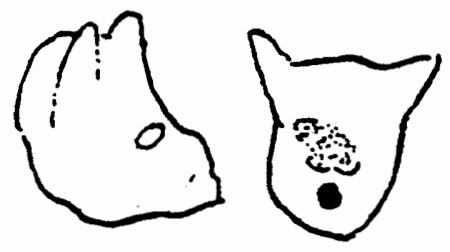

13 yellowish brown (10YR 3/4).

10. Overall, this head is rather crude, although the right ear is fairly well formed. The appearance is vaguely canid or possibly even ursid. It is $39 \mathrm{~mm}$. by $20 \mathrm{~mm}$. by $20 \mathrm{~mm}$. Color is brown (7.5YR 5/4).

11. Animal head. It lacks very much detail. It is definitely not cervid. It is 32 mm. by $15 \mathrm{~mm}$. by $13 \mathrm{~mm}$. and pale brown in color (10YR 7/4).

12. This tiny head is lacking in detail, although it is definitely an animal head. It is $11 \mathrm{~mm}$. Iong and $9 \mathrm{~mm}$. in diameter. Color is pale brown (10YR $6 / 3)$

13. This curious item is tentatively identified as an animal head. Its general appearance is very much that of a pig, but this seems most unlikely. There is a hole in the region that would correspond to the mouth. Unlike the other heads in this series, it is entire and does not seem to be broken off from a more complete representation. of course there always remains the possibility that it was once merely pressed to a 

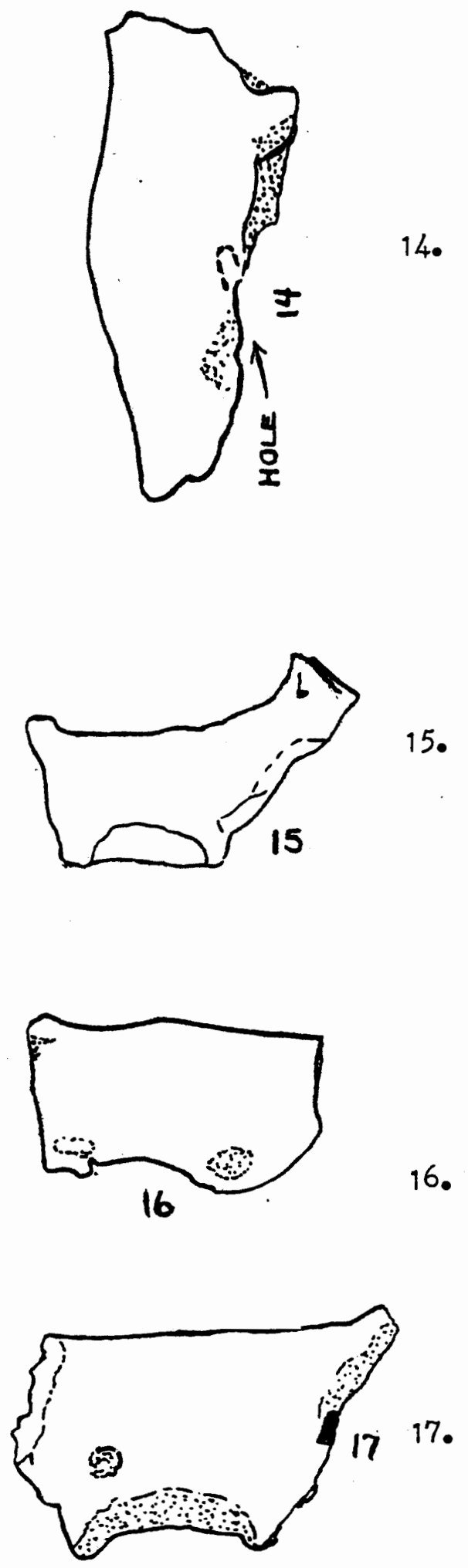

body and became detached during firing. (See \#19 below॰) It is $21 \mathrm{~mm}$. by $21 \mathrm{~mm}$. by $19 \mathrm{~mm}$. Color is dark yellowish brown (10YR 4/4).

14. Animal body. It appears to be a very good approximation of the form of a seal or sea lion. It is fairly well finished. Both head and tail portions are missing. There is a hole on the underside. It is $63 \mathrm{~mm}$. long, $25 \mathrm{~mm}$. deep at the shoulder and $22 \mathrm{~mm}$. wide. Color is brown (1OYR 5/3).

15. This animal figurine is fairly well done. Unfortunately the loss of the muzzle precludes more specific identification. It could possibly be feline. There is no hole. It is $22 \mathrm{~mm}$. long by $19 \mathrm{~mm}$. deep and $16 \mathrm{~mm}$. thick. Color is a dark yellowish brown (7.5YR 5/4).

16. Portion of an animal body. It has a hole in the anal region. It is $37 \mathrm{~mm}$. by $22 \mathrm{~mm}$. by $17 \mathrm{~mm}$. and brown in color (7.5YR 5/4).

Animal body. It has a hole in the anal region. In addition, there is a neat round hole in the left flank as indicated in the drawing. Also, there is 

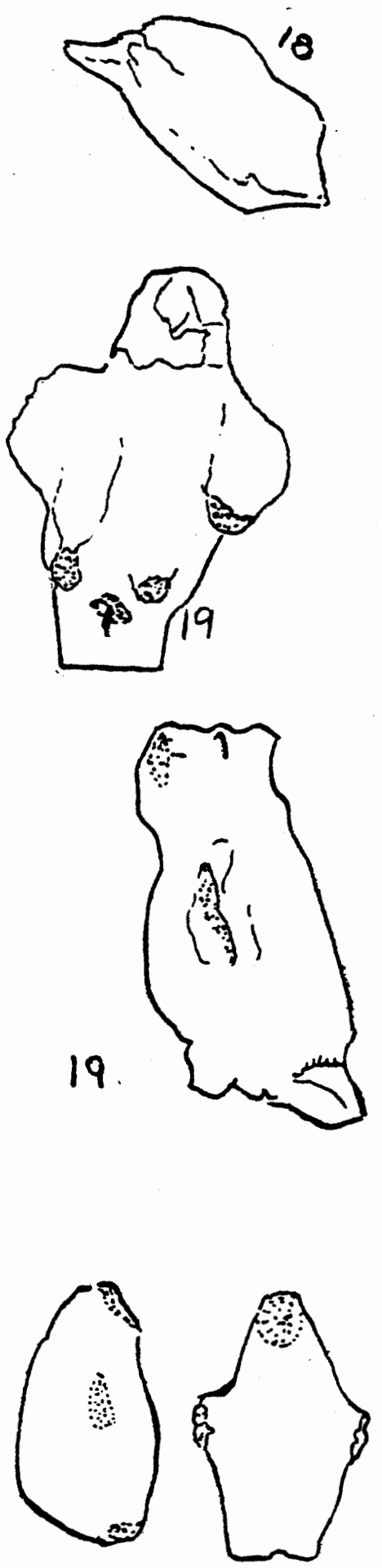

20 an irregular but apparently deliberateIy fashioned hole extending into the right flank at a somewhat higher and more posterior position. It is $43 \mathrm{~mm}$. long, $28 \mathrm{~mm}$. deep and $15 \mathrm{~mm}$. thick. Color is pale brown (10YR 6/3). It has not been shellacked.

18. This is a very crude piece, but appears to be the head of a bird. It is $37 \mathrm{~mm}$. by $13 \mathrm{~mm}$. by $10 \mathrm{~mm}$. and pale brown (10YR 7/3).

19. While it is quite crudely fashioned, this could not reasonably be identified as anything other than an owl. The head appears to have been molded separately and pressed to the body. The eyes are well shown, the ear tufts indicated. Wings and tail are drawn out from the body. Even the legs are indicated, although the tips are broken. There is a hole in the base. Height is $51 \mathrm{~mm}$, width $35 \mathrm{~mm}$, depth $33 \mathrm{~mm}$. Color is dark gray-brown (10YR 3/1).

20. Stylized human figurine without any indication of sex. Part of the head is missing; there is no basal hole. This is $32 \mathrm{~mm}$. by $16 \mathrm{~mm}$. by $21 \mathrm{~mm}$. Color is 


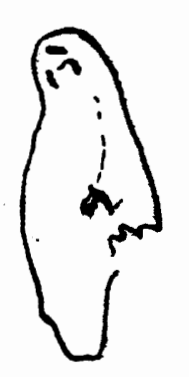

21
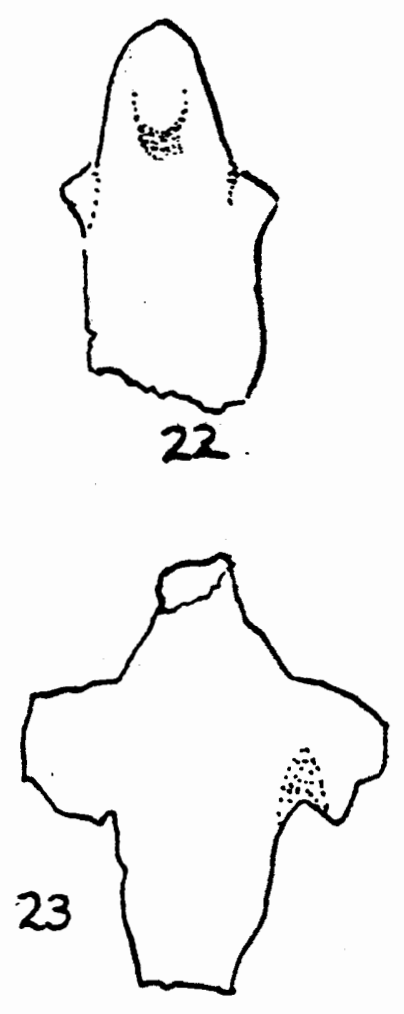

reddish yellow $(7.5 \mathrm{YR} 6 / 4)$.

21. Stylized human figurine. Sex not indicated. The lower portion is missing. The head is entire but lacking in detail. The three marks shown on the left side of the head appear to be deliberate impressions. There are no corresponding marks on the opposite side. It is $33 \mathrm{~mm}$. by $15 \mathrm{~mm}$. by $18 \mathrm{~mm}$. and dark grayish brown (1OYR 4/2).

22. Stylized human figurine. There are no features and no indication of sex. It appears intact except for an area of fracture on the right basal portion. It is $39 \mathrm{~mm}$. by $21 \mathrm{~mm}$. by $18 \mathrm{~mm}$. Color is dark yellowish brown (10YR $4 / 4$ ).

23. Probabiy stylized human figurine. How ever, the extension of the arms is somewhat atypical. The head is fractured. It measures $44 \mathrm{~mm}$. by $36 \mathrm{~mm}$. by $22 \mathrm{~mm}$. and is dark yellowish brown ( 10 YR 2/1)

24. Probably stylized human figurine. The head is broken. It is $33 \mathrm{~mm}$. by $30 \mathrm{~mm}$. by $18 \mathrm{~mm}$. Its color is black (10YR 2/1).

25. Probably stylized human figurine. It is similar in all respects to \#2/4 above, 


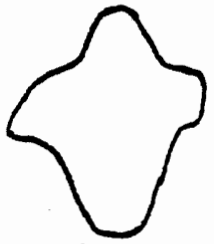

25

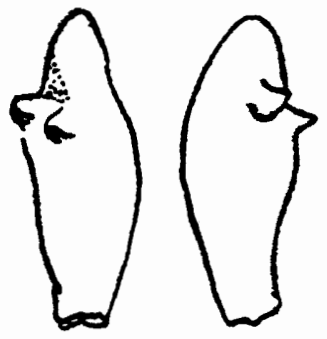

26

but smaller. The item is entire. It

is also black (10YR 2/1) and $23 \mathrm{~mm}$. by $19 \mathrm{~mm}$. by $15 \mathrm{~mm}$.

26. This small and unusual piece was seen by the collector as an animal head, or even as "a snake with ears." However, it is entire except for a small area of fracture at the base and clearly does not seem to have ever been a portion of a complete figurine. Nearly all of the other items which can even be putatively identified as animal heads, do appear to have been part of complete representations. It appears to me that this item could most plausibly be interpreted as a very stylized representation of a human female with the two small projections indicating the breasts. The cylinder is $32 \mathrm{~mm}$. long and evenly tapered with a maximum diameter of 11 mm. Color is brown (10YR 4/3). 


\section{NOTES ON ADDITIONAL ROGUE FIGURINES}

While the four collections described here form the basis of this study, it should be noted that there are other figurines from the aree which, for one reason or another, it was not deemed practical to include.

Jack Benedict of Ashland reports finding a fow figurines and some fragmentary clay material while digging in the Obenchain Mountain area. I have examined and photographed one of these figurines which is now in the possession of a friend of Mr. Benedict's. It appears to be a male human figurine. Mr. Benedict also reports taking a human figurine from a rock shelter on Soda Creek. This item disintegrated when he attempted to wash it. This may indicate the existence of unfired figurines as we11. This same individual did give me one partial figurine and some clay fragments from the Obenchain area. This is the only material I have had for destructive testing.

A Mrs. Dorothy Mason of Shady Cove, Oregon, is supposed to have a figurine of a salmon taken from the Trail Creek region. I have talked to Mrs. Mason by phone but have been unable to examine this specimen.

Mr. Hilyer Liligren of Medford has a single human figurine taken from a site on Jackson Creek. This is on the South Jmpqua rather than the Rogue drainage, but it is separated from the Trail Creek area by only a low divide. This is the only figurine among about 2,000 catalogued items taken from Jackson Creek and vicinity, so it would appear to be anomalous to that area. 


\section{EXPERIMENTAL WORK}

Experimental work with Rogue Valley figurines has been of a linited and preliminary nature due to lack of available material and facilities.

Fragments immersed in water for up to three weeks appear to remain unaffected. Also, a few samples have a blackened appearance. From this it is inferred that the items were fired at low temperatures in an uncontrolled atmosphere (probably by merely being thrust in an open fire) rather than having been only sun-baked.

The figurines are rather soft with a hardness of three to four on the MOHS scale. None show any evidence of paint or pigment. No microscopic examination was done to determine the nature of the temper.

It was hypothesized that the Rogue figurines were made from localIy available clays, and that the only temper was naturally included material. It was further thought that they had been fired in an uncontrolled atmosphere, i.e., an cpen fire. From the appearance of the figurines, it was felt that little or no skill was required in their manufacture, that possibly they might have been made by small children.

To test these possibilities, I tried to replicate the figurines. First, I obtained clay from Snider Creek near a point where many of the figurines were found. I mixed and kneaded the material thoroughly, removing coarser bits of rock and plant material; the clay appeared to have a considerable inclusion of sand but was fairly elastic.

For this test, four figurines were attempted: male and female human forms, a cervid head with eyes of clay balls appliqued and a small 
quadruped. It was readily apparent from this attempt that the figurines did require considerably more skill and experience than was originally supposed. Despite my repeated efforts, the figurines did not match the workmanship of those seen in the collections. This could indicate that considerably more care had been used in the selection of the clay, or that the artisans had developed some skill through practice or possibly all three.

In any event, this tended to discount, although not entirely rule out, the notion I had entertained that the figurines could have been made by children playing in the mud but rather supported the view of Harry Shafer to whom I had previously sent photographs and descriptions of some of the figurines. Dr. Shafer said he doubted that the objects had been made by children. (Shafer, Personal communication 1977) This initial lot of four experimental figurines was allowed to dry for a week and then heated in an open fire. All of the objects survived firing and appeared somewhat like those in the collections, though as mentioned, were less well-executed. 
A NOTE ON THE AUTHENTICITY OF THE ROGUE FIGURINES

When I first became interestad in this project, Mr. David Colo of the Museum of Natural History at the University of Oregon warned me that I should beware of fakery as all of the figurines were in amateur collections, and none had ever been unearthed by a professional. This is a point well taken, and one that must be addressed. Certainly there have been a vast number of archeological fakes produced at one time or another. It should be noted, however, that the great majority of such fakes are produced for profit, while a lesser number of fabrications are the work of notoriaty seekers, and in a few instances, as may have been the case in Eanthropus dawsonii, they are the work of practical jokesters.

None of these motives would seem to apply here. None of the collectors has, to my knowledge, ever sought to sell the items or implied that he felt they were items of great monetary value, nor have they regarded them as outstanding items in their collections. Since they have been found by a number of individuals over a period of at least thirty years, the notion that they may be acting in conspiracy to play some sort of trick on the archeological community seems, to say the least, somewhat paranoid.

It must also be noted that in addition to the material here presented, i.e., the more or less recognizable figurines, most of the collections contein a large amount of material broken beyond recognition. As cen be seen from the illustrations, many of the items are poorly exe- 
cuted. It seems unlikely that anyone deliberately producing archeological fakes would retain this sort of material.

Likewise, the idea that the items could have been produced as a practical joke by individuals unknown to the collectors and then left at the sites to be "found" would seem to imply a vast and utterly pointless conspiracy.

I see no good reason to doubt that the figurines are of aboriginal manufacture or that they were found in the general area where the collectors claim to have found them. 
THE DISTRIBUTION OF ROGUE FIGURINES IN RELATION TO

WHAT IS KNNOWN OF ABORIGINAL POPULATION DISTRIBUTIONS

It must be said at the outset that the age of these objects can only be surmised. All of the figurines and associated pottery have been recovered by amateur excavators working without controls. Each of the collectors was able to state that the figurines had been taken from the upper levels of the sites excavated, and that these same levels had yielded Gunther style points. In some instances, deeper excavation had produced what the collectors termed "punkin seed" points. These would be the Gold Hill style. However, no pottery or figurines were found at these deeper levels. There is also some indication that the items were associated with glass beads and other European trade items.

All of this lends credence to the notion that the figurines are of fairly "recent" origin, although we must cautiously allow the term to apply to a time depth of at least several hundred years B. F. Certainly there is no indication that the figurines are of great antiquity. As to their spatial distribution, we can be considerably more definite. Map number one shows the sites in the area which have yielded figurines and pottery as well as those sites in the immediate vicinity which have been investigated and found not to contain ceramics.

Most of the figurines in these collections have come from Snider Creek. This small tributary of the Rogue rises five miles north of upper Table Rock and flows south between upper and lower Table Rocks to join the Rogue just upstream from its confluence with Bear Creek. 
Additional figurines have also been reported near the mouth of Trail Creek and in the Obenchain mountain area, while sites on Jackson Creek and Soda Creek have yielded one figurine each. All of the collectors involved have prospected numerous other sites immediately outside of these areas but have never found potiery or figurines at other than the locations given.

The first professional archaelogical work in the Rogue Valley was done by Cressman, who excavated the Gold Hill site in the early 1930's. While a large number of items were found, and a possible occupational depth of 4,000 years was inferred, no pottery or figurines were found. (Cressman 1933) In 1958, Newman did a surrey and salvage excavation of a rock shelter prior to the construction of the Emigrant Lake reservoir on the upper reaches of the Bear Creek watershed. In this same area, an amateur, Higene Brown, conaucted a fairly well controlled excavation of a rock shelter on Cove Creek in 1969. While more than 300 items of cultural material were catalogued in this latter excavation, there was no clay. It appears that had even crude figurines or pottery been present at this site, the excavators would have recognized them. More recontly, David Brauner conducted salvage excavations at the Lost Creek dam site. These too vere negative for pottery and figurines. (Lavis 1972)

Most recently, excavations were carried out during the sumer of 1973 by Brauner on the upper Applegate River. Again, no ceramics were found. (Brauner 1978) During the same summer, limited test excavations of a site furthe: down the Rogue River at the mouth of Mule Creek, produced no fizurines or pottery. (Neilsen 1978)

While statements concerning the non-occurrence of an item are 
always difficult to support, it appears that the distribution of the figurines and the pottery is restricted to the Rogue River drainage from the level of Table Rock up stream to Trail Creek, and that the Bear Creek Valley, or at least its upper reaches, is excluded.

What we actually know of aboriginal population distributions is also limited. All of the Indians in the Rogue area were rounded up in the summer of 1856 and sent to the Siletz Reservation where they were merged with numerous other groups from western Oregon, and individual cultural identities were rapidly lost. Further, this event had only been the culmination of years of warfare, epidemics and massive displacements of native populations.

Only three anthropologists ever worked directly with people from this area. And in each case they were working with informants many years after resettlement on the reservation. In 1884, Owen Dorsey published a short article on the Takelma. In 1906, Edward Sapir visited the reservation and wrote a brief ethonography on the basis of information supplied almost entirely by a single lowland Takelma informant, Frances Johnson. Finally, in 1930, Phillip Drucker worked with Molly Orton and upland Takelma. Additionally, some information was provided by Spier and also by Dixon in their work with the Klamath and Shasta, respectively. All other accounts of local aboriginal people appear to derive from these sources.

All of the available information indicates that the Rogue River, from about the mouth of the Illinois upstream to Table Rock, was occupied by the lowland Takelma. However, within this area there were enclaves of Athapascans on Galice Creek and the Applegate River. Upriver, beyond Table Rock, and along the drainages of Big and Little Butte Creeks were 
the Latgawa, or upland Takelma, a group that was closely allied culturally and linguistically to the lowland Takelma but considered poorer in material resources. This division at the level of Table Rock also coincides with a division in fisheries resources, as it is generally considered the upper limit of the Chinook spawning area. Still further upstream, at the headwaters of the Rogue, were the SouthernMolalla, apparently a small and very recently intrusive group. According to Spier's Klamath informants, they wintered a little below Frospect. This could have coincided with the present Lost Creek reservoir, which is a few miles down from Prospect and certainly about the highest point on the Rogue which would have provided an attractive wintering area.

The status of Bear Creek valley to the south of Table Rock is less certain. The region was claimed, by Takelma informants, to have been upland Takelma territory and seems to have been used by the Takelma at the time of White settlement. However, Dixon's Shasta informents also claimed Bear Creek valley. After a recent review of the available evidence, Julia Follansbee has concluded that both the Shasta and the Takelma utilized Bear Creek valley. (Follansbee 1978, p. 23)

It would appear then that figurines and pottery are found in those areas that are unquestionably upland Takelma. The Gold Hill site in an area that was clearly lowland Takelma, and the Applegate sites, presumably occupied in recent times by Athapascan speakers did not yield ceramics. There are two possible explanations for the lack of pottery and figurines at the Iost Creek reservoir sites. First, it is possible that the figurines are a very recent innovation, and that by the time they appeared, the Southern Molalla had displaced the Latgawa at these sites. However, it seems to be most unlikely that the Latgawa, who had a 
reputation for ferocity, would have voluntarily ceded any firmly occupied territory to a small and weak group such as the Molalla. Further, the lack of any mention of figurines and pottery in any of the ethnographic material would cast doubt on the notion that the manufacture of these items persisted into the time of contact.

Had the clay manufactures been limited solely to figurines, I would not take this lack of mention in the ethnographic literature as a serious indication of their non-manufacture at the time of Euro-American contact. After all, as had been pointed out, the ethnographic record is flawed. If the production of figurines had been an exclusively male pastime, or a children's game, it is understandable that they might have been omitted in the remembrances of Drucker and Sapir's elderly female informants. But large quantities of crude pottery were also taken from the Snider Creek site. It seems most unlikely that utilitarian clay vessels could have been "missed" even in these limited ethnographic studies had they actually been utilized during the informants' lifetimes.

A more tenable hypothesis would be that the figurines and the pottery as well were associated with the winter activities of the upland Takelma. Indeed, if a transhumant hunting and gathering existence is inferred for these people, then ceramic manufacture would more logically be associated with the semi-permanent winter villages than with the mobile summer encampments. If the Latgawa had over-wintered in the Table Rock area and utilized the slightly higher and somewhat less favorable areas around Lost Creek only in the summer, while the Molalla, arriving later on the scene, wintered in this latter area but disbursed into the Cascades during the summer, then both the lack of conflict between the two groups and the absence of figurines in Davis's Lost Creek excavations 
can be explained.

Also this explanation does not force the appearance and disappearance of figurines into an almost impossibly compressed time period of little more than half a century. What then seems possible is that pottery manufacture goes back somewhat further than the appearance of the Southerm Molalla upon the scene. However, this still nascent art was a culture trait that was lost during the stresses that Rogue Valley people had been undergoing for nearly 50 years prior to White settlement. While none of this can be firmly established on the basis of present data, I would suggest the following as hypotheses to be tested:

1. The manufacture of ceramics within the Rogue River area was a distinctive trait of the upland Takelma;

2. Ceramic manufacture was a winter activity;

3. The manufacture of figurines and pottery was a fairly recent introduction or invention;

4. This industry had declined or been lost by the time of EuroAmerican settlement.

The map on the following page details the location of these sites. 


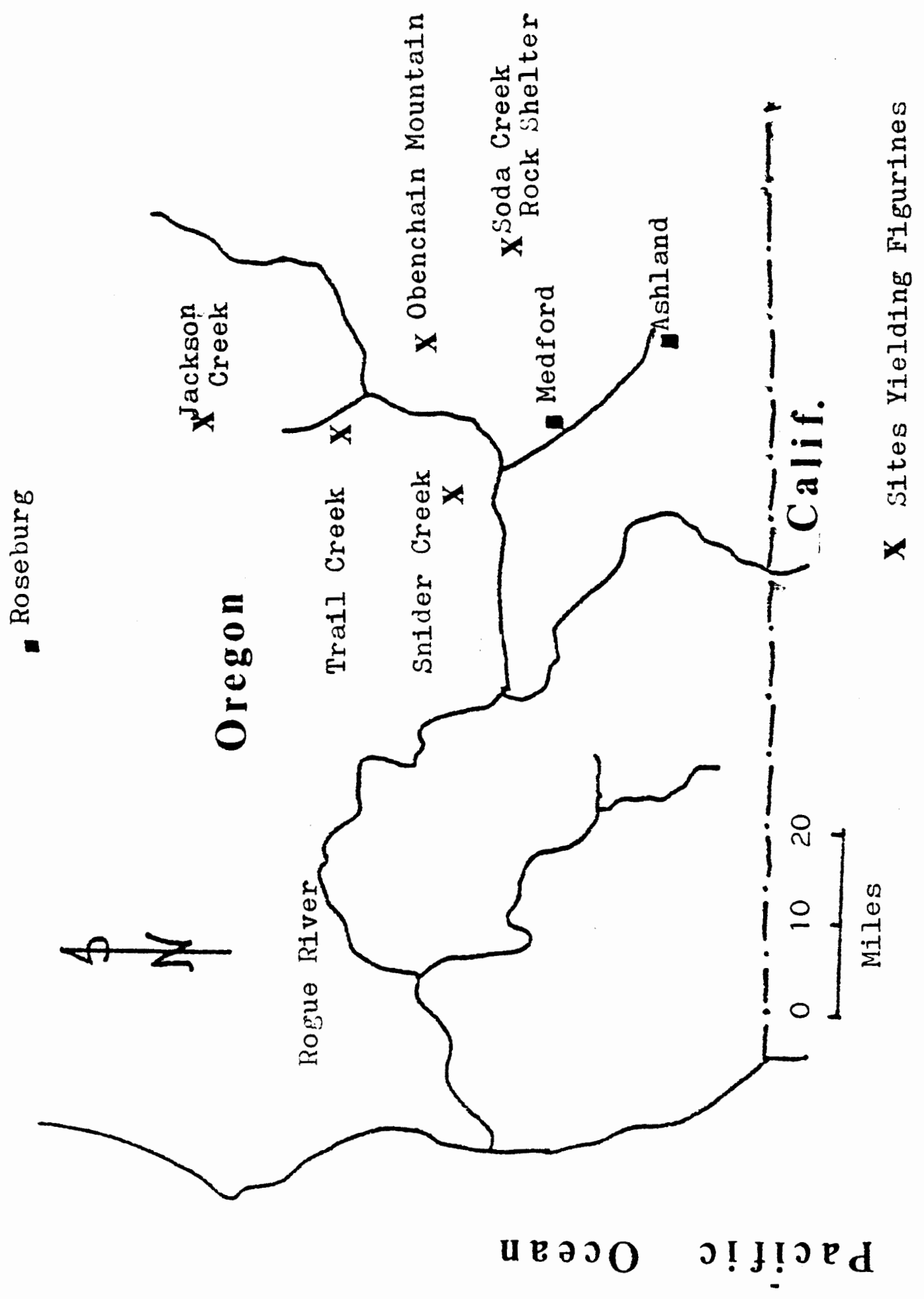




\section{INTERPRETATION}

There are various ways to develop a typology of the figurines, but most obvious would be on the basis of what is represented. The first division would be between human and animal representations. The humen figurines can be further divided into those that are male, those that are female and those in which sex is not indicated.

There has been a tendency, no doubt due to the fact that most figurines throughout the world are plainly female, to regard any figurine lacking breasts or female genitalia as male. Meighan argues, I think correctly, that this assumption is unwarranted. Probably these figurines clearly were male or female in the eyes of their makers. Artists do not ordinarily render representations of persons without regard for sex, but the distinction is often made on the basis of some convention not clear to an outsider.

Therefore, any comparison of sex ratios in human figurines will be based upon those that can be readily sexed. This of course means that any such ratios will be suspect to the extent that they might be changed if the sexes of all the figurines were known.

The animal representations can be divided into cervids and noncervids. Heads of cervidae are the most common. Beyond this, a considerable number of species are represented but many by only a single figurine. Therefore, interspecific numerical comparisons are not possible, but the total range of species represented, and the fact that certain species are seen at all, may be significart. 
Thus, the set of categories to be set up will be as follows:

I. Human representations

A. Females

B. Males

C. Indeterminate

II. Animal representations

A. Cervidae

B. Non-cervidae (total number of species identified)

Secondly, we can consider the figurines from the standpoint of various characteristics of manufacture. The first of these is the presence or absence of the so-called "spit hole." This is a hole in the basal portion of the figurine which may indicate the wet clay had been formed upon a spit. The presence or absence of the feature cannot be determined for some specimens which are not entire, therefore, the number assigned to these categories will be less the entire sample. Other possibilities would be to divide our sample on the basis of the presence or absence of incised decoration, the employment of appliques, or conversely, indentations, to represent the eye.

Whatever else they may have been, ana no matter how the figurines actually functioned, all figurines are representations. The subject we are here concerned with is: "What is represented?" Now, representations may be fashioned after things experienced in reality, but this is by no means a necessity, as the great number of representations of dragons, unicorns, mermaids and other fanciful creatures will attest.

Further, the number of points of correspondence between an artistic representation and the thing it represents is highly variable. Certainly in many cases some convention is the only way a connection may be 
made between subject and representation, and if one is unfamiliar with the convention, then there is no way to understand just what has been represented. At this point, we may be leaving the realm of art for that of language.

However, we do not know and seemingly have no way of knowing the conventions of the artisans who produced the Rogue figurines. Therefore, we can only interpret the figurines on the basis of resemblances that we ourselves see between the figurines and potential subjects.

With many of the figurines, the resemblances are so obvious that this is no real problem. For example, item \#5. in the Caroline Jensen collection quite obviously represents a human female form, and while it might be argued that a human female form could itself be adopted as a convention to represent practically anything, there is no quibble as to how the form itself was originally derived.

But there are others for which the resemblances are certainly not obvious. There are, in particular, several "human" figurines whose humanity could be questioned. Good examples are Roy Reed, item \#4, and Ray Peery items \#23, \#24 and \#25. Some of these have not been seen by the collectors and others as human representations.

However, all of the figurines which are reasonably clear representations of anything (and these comprise the majority) are representations of animate subjects, that is, people or animals. There are no apparent representations of inanimate objects. Therefore, where representation is not ciear, I have considered the figurine a human representation if that is only somewhat more plausible than considering it to be animal. In part, this is due to a wish to play Devil's advocate for the moment, since one of my conclusions will be that these figurines differ from the 
majority of those found throughout the world in exhibiting a preference for animal as opposed to human subject matter. I wish to strengthen this at the outset by interpreting as human all of those figurines which could conceivably be so interpreted.

On this basis then, of the 80 figurines here presented, 23 can be classified as human and 57 as animal. If we then pose the hypothesis: Animal subject matter is more common than human subject matter and apply the Chi square test,

HUMAN

23

40

17

289
ANIMAL

57

40

17

289

$$
x^{2}=\frac{289}{40} \quad-\quad \frac{289}{40}=14.45
$$

and the critical value for $x^{2}$ at 0.005 is 7.87944 . Therefore, the hypothesis that there is a simple preference for animal over human subject matter is sustained at $99.5 \%$ confidence. Of course, with this small sample, it is difficult to go much beyond this. For example, the odds are only 40 to one that the preference was as high as $60 \%$, and of course no better than even, that the $71 \%$ preference for animal subjects would be equalled or exceeded in the total figurine population.

Works dealing with figurines are few, and most reports deal only with a few items. Meighan's 1953 dissertation seemingly stands alone as a general work on the subject. From this treatise dealing with more than 6,000 figurines world wide, the raw data indicate a majority of animal over human figurines only from one sample from northerm Arizona, 
and here the preference is too slight to be of much significance. In this respect at least, the subject matter of the figurines seems to differ from those found elsewhere.

Further subdivision of the human figurines shows that three are male, five are female, and sex is not clearly indicated in the other 15 cases. We might suppose that in some of these, sex might be indicated by decoration rather than the portrayal of primary or secondary sexual characteristics, but only three of these unsexed figurines show any attempt at decoration. Since the sex of the subject is generally implicit in any human representation, it is difficult to accept the notion that these figurines somehow represent asexual "persons." Sex may have been understood either because the figurine was used by the individual who made it and could, by imagination, endow it with sex, or the sexuality of the figurine was implied by the context in which it was used.

However, it must be emphasized that the sample contains unequivocal examples of both male and female human figurines. of course our sample of three males and five females is too small to admit of any farreaching conclusions as to general sex ratios. Even so, some observations are in order. Meighan (p. 131) using a sample of 541 dolls, notes that $11 \%$ are males. If the percentage of male figurines in the Rogue Valley were no more than that, the odds are no more than one in 20 that a sample of eight figurines would contain three males. The mathematics in support of this are as follows:

$$
\begin{aligned}
p(y) & =c_{y}^{n} p^{y} q^{n-y} \\
p(3) & =c_{3}^{8}(.11)^{3}(.89)^{8-3} \\
& =\frac{8 !}{5 ! 3 !}(.001331) \quad(.5584059) \div .0416213
\end{aligned}
$$


To be completely accurate, we would also have to consider the possibility of four or more males being drawn, but these are too remote to raise the total probability beyond .05 . Thus, there is a hint that male figurines may be more common than in Meighan's sample.

When we turn to the animal representations in our sample, three observations are immediately apparent. First of all, there are a considerable number of heads of cervidae, that is, of what appear to be deer or elk. Secondly, representations of heads alone outnumber those of entire animals. Thirdly, and perhaps most significantly, a great number of different species of animals are represented. Thus, at least 17 of the figurines, or slightly less than $30 \%$ of the animal sample, are either very definitely or most reasonably seen as representations of deer or elk. Thirty-eight specimens, or two-thirds of the animal sample, are of heads only. Finally, the entire collection of 62 specimens can be seen as representing no fewer than twelve creatures other than deer and $e l k$ and very probably somewhat more than this. Thus, while deer and elk heads are more common than any other single type of representation, they are clearly not preferred over all other types of representations combined. Therefore, I would say that the overall tendency was to represent a wide variety of animal species with a moderate emphasis on deer and elk.

Whether the presence of a large number of representations of animal heads only, as opposed to bodies or complete bodies with heads, is a representation of the universe of figurines or a function of collector behavior is a moot point. There are only eight examples of a relatively complete specimen including both head and body, and this includes two fish. Nearly all of the heads do show a fractured surface at 
the base of the neck. Further, the bodies which do appear are often quite crude; for example, see \#15, \#16 and \#17 in the Roy Reed collection. Therefore, it seems entirely possible that the bodies were often not recognized and not saved by the collectors.

Turning to the so-called spit hole noted in a number of the figurines, we find this trait present in 19 specimens and apparently absent in twelve. In the remainder, the figurine is either too fragmentary or is mounted in such a way that we cannot determine the presence or absence of this trait. In 11 instances this hole clearly corresponds to the placement of the anus in a quadruped. In one instance, the anus of a bird, and in another, the anus of a fish seem to be represented. However, it must be pointed out that there are two quadrupedal figures and one fish and one bird which clearly lack this feature. It may also be noted that where a deeply penetrating hole is seen in a human figurine, it never seems to indicate an anatomical orifice such as the anus. Obviously these are rather small samples to draw any firm conclusions from, but it would appear that the anus was usually represented in animal figurines but not in human representations.

As to other traits of manufacture such as the use of incised decoration, the use of either punctate marks or spherical appliques to represent an eye or the degree of detail used in the execution of any item, we can only say that our sample shows great variability. 


\section{INVENTION VERSUS DIFFUSION}

Still to be considered is the question of whether the manufacture of fired clay objects was a local invention or an idea imported from abroad. First, it can be stated that the Rogue figurines were made at, or near, the sites where they were found. The presence of a large number of broken and poorly formed items along with pieces obviously damaged in manufacture, such as Ray Peery \#5, makes it seem unlikely the figurines were imported.

A number of factors govern the diffusion of any item. Sometimes an item may be copied if it is merely seen. Thus, the Russians would be quite capable of reproducing an American military rifle from an example of the piece itself. It would probably not be necessary to demonstrate the operation of the rifle and details of its manufacture. On the other hard, if people unfamiliar with atlatls were show one, they woula have no idea of its use without a demonstration. Having seen this, they could no doubt manufacture and use atlatls themselves. How ever, sometimes an item can successfully be passed from one culture to another only if the process of manufacture itself is related. This condition could apply to the diffusion of fired clay figurines. There is no way that one, by merely watching people drink from fired clay mugs or using fired clay effigies, could duplicate these items without an explanation of the firing process.

This could take place in two ways: either an individual from 
the Rogue Valley would have had to travel to some area where clay was fired and returm with a knowledge of the process, or an individual from a culture which manufactured fired-clay objects would have had to immigrate to the Rogue Valley and teach the process. Fither one is possible only if we can find a source of ceramic manufacture which is reasonabiy close both spatially and temporally. Fore example, many of the animal heads seen here are reminiscent of those found at Karim Shahir in Iraq, but it would be pointless to pursue a connection between two phenomena separated by half a world in space and at least several millenia in time. We must also, in our search for a source, consider known or suspected routes of diffusion for other items. As I have stated before, little is known regarding this area. However, Cressman initially postulated that the Rogue Valley people were under strong influence from the northwest coast. This idea has been strengthened by subsequent work. Therefore, we should begin our search for a possible connection in this area. Generally, few figurines have been found on the northwest coast.

There have been a number of isolated finds of figurines along the lower Columbia, but the only sizeable collection of figurines from that area, and indeed the only sizeable collection of figurines from the northwest other than the Rogue figurines, is from the Herzog site near Vancouver, Washington. (Slocum and Matsen 1968) The question immediately arises as to whether or not there can be any connection betiween the two. As with the Snider Creek site, the Herzog site is not well dated, although it appears to have been occupied until contact times. Therefore, we can make no assumptions involving the relative time of appearance of the objects at the two sites nor assume they are contem- 
poraneous. The authors note that this collection contains both very crudely fired and unfired specimens. So far as the relative workmanship of the items is concermed, I have not been able to examine the Herzog specimens: However, from the very good photographs published by Slocum and Matsen, it does not seem that either sample can be seen as showing more development of technique than the other. Beyond these aspects, however, the two collections differ markedly.

First, not one of the 84 specimens from the Herzog site can be identified as an animal representation (though admittedly some of the unadormed rods or cones depicted could conceivably have served as appendages on animals). Among the Rogue figurines, animals were clearly the preferred form of subject matter.

Secondly, of the several figurines from the Herzog site which are obviously human, not one has any indication of sex. While the majority of the small sample of human figurines from Snider Creek are without indications of sex, there are also clear examples of both male and female figurines.

A more striking difference is the extensive use of incised decoration as seen on the Snider Creek figurines, it is far less frequent and not early as extensive on the specimens from the Columbia.

Overall then, we can say that the two sets of figurines are similar in the level of technological development but differ almost totally in respect to style and subject matter. The only notion common to the two sets of makers which can be supported by these items is the general idea of shaping and firing clay. We can hardly consider it remarkable that human likenesses are seen at both locations.

In addition, there have been sporadic finds of figurines from 
northern California. The few examples reported by Heizer and Pendergast do not seem to compare in style or subject matter to the Rogue figurines. In any event, the number of northern California figurines from any one locality is at present too small to admit any comparisons.

Finally, it should be noted that a strong resemblance has been noted between $\# 26$ in the Ray Peery collection and one reported by Shafer from the lower Pecos region in Texas. (Deich 1977) This, however, is a bit distant. Also, Shafer has dated the Pecos figurine at 2000 B.P., while there is little or no reason to suppose the Rogue figurines possess any such antiquity. (Shafer 1975 \#1)

Both figurines are highly abstract representations of human females, or at least they have been so generally interpreted. Each is a cigarshaped object with two conical projections about one-third of the distance from one end, which are seen as breasts. Certainly this interpretation is not unreasonable. However, the resemblance between the two objects could certainly be seen as arising from limited possibilities. Representation of the human form by a rod or cylinder is too common to require comment, and certainly the indication of female sex by endowing the object with breasts is widespread.

While the Rogue Valley is certainly not an island unto itself, and it is plausible that the notion of making and firing could have been derived from elsewhere in North America, no connection can he made between the Rogue Figurines and those found elsewhere on the basis of the admittedly limited evidence we now possess. 


\section{USE AND FUNCTION OF THE FIGURINES}

In everyday parlance the terms use and function are often interchanged, yet their meanings, especially in anthropology should be kept distinct. Use simply means the direct and immediate application for which an object is fashioned and the one usually seen. Function, on the other hand, is the overall effect which the object has within the context of a given cultural setting. For example: firearms are used to kill people. They are also used to kill animals or make holes in paper targets. A revolver might even be employed as a net weight or tack hammer, but these uses are hardly the intended ones.

However, we may say that in eighteenth century England, firearms functioned to maintain the centralized authority of the royal establishment. They functioned in the American Colonies to ultimately abolish the Royal authority. Thus, while firearms were put to the same use on both sides of the Atlantic, they held different functions due to the differing social status and perceptions of shooters and those at whom they shot. An understanding of use then, requires no knowledge of the social position of the user. Function, however, does require such knowledge.

Meighan has pointed out that the function of non-utilitarian items can ordinarily only be interpreted from context. (Meighan p. 117) In the absence of better ethonographic data or the discovery of figurines in good archeological context, all statements regarding their use or function remain conjectural. This doesn't prevent exploring ways 
in which the figurines may have functioned and at least suggest that some appear to be more plausible than others.

There are, however, two cautions suggested by Meighan in this regard. First, there is a tendency among archeologists to overestimate the significance of the items they study. Thus, every female figurine becomes a fertility goddess and every animal representation some sacred totem. Secondly, too few possibilities are considered. Actually, the number of functions a non-utilitarian object might have had is bounded only by the limits of human imagination .

A list of possible functions might include the following:

1. Grave goods,

2. Symbolic offerings or sacrifices,

3. Tokens of value in trade or exchange,

4. Children's playthings,

5. Employment in sympathetic magic,

6. Household idols.

Or, the function, instead of relating to the objects themselves, may have resided in the process of manufacture. They might, for example, have been made as:

1. A time-filling activity to relieve boredom, much in the manner of doodles made by a telephone calier who has been set adrift on the hold button,

2. Part of a game or contest,

3. A penance.

These lists are by no means exhaustive. As we have indicated, the possibilities are endless. It is perhaps not inappropriate that the author spent Mickey Mouse's fiftieth birthday examining a collection of 
Rogue figurines and speculated as to what conclusions future archeologists will base on the celebrated rodent and his many kin.

First of all, while all of the collectors involved have freely admitted to digging in burials, all were emphatic in stating that the figurines were never found in this context. Thus, it seems unlikely that the figurines have served as mortuary offerings, grave goods or servants for the dead in an afterlife.

Secondly, there are certain inferences which are suggested by the lack of standardization and variety of subject matter. We would ordinarily expect cult objects or idols to show more uniformity of appearance. Thus, if we found a number of relatively similar human figurines, especially with repeated stigmata, we might reasonably state that we were dealing with a cult object or idol. But, obviously, this is not the case.

Likewise, if we were to advance the idea that the figurines were token sacrifices, we would again have to consider the variety of subject matter. Prescribed sacrifices tend to be rather specific. As the tale of Cain exemplifies, God may be considered omnipotent but hardly omnivorous, thus, while we can conceive a ritual in which small clay replicas of one, or a few, prized animals are thrown into a fire as sacrifices, it is somewhat more difficult to imagine that the managerie represented here could have been so utilized.

Some might also suppose a lack of religious significance from the generally low quality of workmanship exhibited. However, I do not think this point very important. While it is true that some of the highest degrees of art and craftsmanship are sometimes seen in religious objects, it is just as often found that such objects may be in execrable taste 
and shoddily made. Rather, it is because of the variety of these objects that I would reject the idea of a religious function.

Notions that the figurines might have been used in magic or witchcraft have also been advanced. While there is no reason that the human figurines could not have been used in some form of witchcraft, there is nothing to support the idea either. Of course, if we were to find a human figurine pierced by several needles, an example given by Meighan, then witchcraft would be a very logical supposition. It is plausible enough to suppose that figurines of deer, elk and salmon could have functioned in some form of magic directed at attaining success in fishing or hunting or securing an increase in desired species. However, it is much more difficult to use this as an explanation of representation of cougar, owl or woodrat.

If the figurines were not associated with mortuary practices and were very probably not associated with religion or magic, what are some of the more mundane purposes to which they may have been put? The first one that comes to mind is that they may have been toys. Despite what was said earlier, it is not entirely impossible that they could have been made by children. Indeed, Fewkes shows figurines made by a fiveyear-old Navajo girl which compare favorably with many in this series (Fewkes 1924) The idea that the items were children's toys could certainly account for the variety of forms found, for the fact that there are both males and females among the human representations and the fact that non-game species are found among the animal representations, also the fact that there are apparent representations of animals which are not indigenous to the area, or which may even be mythical. 
of course the supposition that the figurines were toys does not mean that they were necessarily made or used by children. They could have been used by adults as tokens or counters in some sort of game, much as we use chessmen or the little playing figurines that are moved about upon a monopoly board. Overall, I would say that the notion that the figurines served as playthings for children, or even adults, is a wholly reasonable one, although one that would be difficult to prove, unless some of the items were recovered in really ideal context.

The final possibility to be considered here is that the function lay only in the process of manufacture. Is it possible that they were made only to pass the time while the makers were waiting for some other event to take place? For example, is it possible that they could have been made by hunters while waiting at a game stand? Perhaps, but there is nothing about the Snider Creek site which would make it especially good for this purpose. It is in the center of a large level area without a commanding view of the surrounding territory, and while animals could come here to drink, they could just as readily have drunk at any other point along the creek.

Also, it is probable that items made merely to pass the time would be made from some material readily at hand, either naturally, or as a residue of the primary activity. Clay is abundant at the Snider Creek site and at the other places where figurines have been found. While some of the cruder specimens could have been fashioned from clay taken directly from the creek bank, most would have required some preparation of the clay-at least the removal of some inclusions, and perhaps the addition of clay as well. It would seem unlikely that hunters would have prepared clay in this manner, to be used merely as a time-filling 
activity, while waiting for game to arrive.

But the Snider Creek site, at least, has yielded large amounts of very crude pottery. In fact, if Mr. Peery's collection is representative, the volume of the pottery vastly outweighs that of the figurines. Now, while Meighan has pointed out that there is no necessary or universal association between pottery and figurines in this instance, the association is unquestionable. Now, if Snider Creek represents a primary site for the manufacture of pottery, there would have been a residue of clay left over from the manufacture of utilitarian wares. What may well have happened is that some of the potters, while waiting for their other wares to fire, fashioned remnant bits of clay into various shapes to amuse themselves. These could have then been tossed into the fire. 


\section{CONCLUSIONS}

This study points out the need for the archeologist to examine amateur collections seriously, especially where there has been little professional excavation. Consideration of these collections will vastly extend the artifactual universe. This is important where we are concerned with the total range of variation to be found in artifacts, and it would be out of order to conclude that a particular item did not occur in an area unless all sources, both professional and amateur, have been consulted.

But, if we expect much more from these collections, we are apt to be disappointed. Many items in emateur collections cannot be associated with a particular site, and almost none can be given provenience within a site. However, the general area an item came from is usuelly known. Most collectors are interested in inter-areal differences in artifiact styles; for example, the differences which may be observed in projectile points between the coast and the interior or the distribution of an item such as the figurines; but few will be concerned with minute differences between two similar sites a few miles apart.

Also, we must remember that while all collections, both professional and amateur, are biased, the biases of a professional excavator whose research design and excavation methodology are known, can be determined. The biases of amateurs can only be surmised.

So far as the figurines themselves are concerned, we may soinclude:

1. That they are associated spatially with territories occupied 
by Upland Takelma at the time of contact;

2. That there is a preference for animal rather than human subject matter;

3. That there is a wide range in both style and subject matter, with a variety of creatures represented and both realistic and abstract forms being found.

4. On the basis of present information, there is no demonstrable connection between these figurines and those found elsewhere in North America;

5. Regardless of how the notion of making figurines may have been derived, it appears that the figurines themselves were manufactured here rather than imported;

6. That while function remains speculative, there are very good reasons to doubt that the figurines had any religious or magic significance or that they played any part in mortuary practices;

7. That it is plausible that they were children's toys or were manufactured as a time-passing activity.

Additional investigation of both figurines and pottery in the Rogue Valley is indicated. This would depend upon controlled excavation of sites known to contain these items. Dating the objects would be of the utmost importance if they are to be definitely associated with the Upland Takelma and would be also necessary to further investigate the possibility of any connection between clay manufactures found here and those from other areas. Certainly it is to be hoped there will be more research into southwest Oregon Clays. 
Braumer, David (1978) Personal communication.

Bryan, A. L. (1959) "Two Clay Figurines from Southwest Washington," Tebiwa, (2), \#1, 59-64.

Cressman, Luther (1959) "Final Report on the Gold Hill Burial Site," Oniversity of Oregon Studies in intihropology, (1).

Davis, Wilbur (1968) "Arcineology of the Lost Creek Dam Reservoir," Report of Oregon State University to the National Park Service.

Davis, Wilbur (1972) "Lost Creek Archeology," Report of Oregon State University to the National Parik Service.

Deich, Lyman (1977) "Aboriginal Clay Figurines from the Rogue River Area," Paper presented at the Oregon Academy of Science, Annual Meeting, University of Oregon, Bugene, Oregon.

Dorsey, J. O. (1884) "Indians of the Siletz Reservation, Oregon," American Anthrodologist, Old Series, (2), 5j-61.

Drucker, Phillip ( 1939 "The Tolowa and their Southwest Oregon Kin," University of California Pubiications in American Archeology and Etbonography, (36), 294-296.

Farnham, Wallace (1955) "Religion as an Influence in Life and Thought: Jackson County, Oregon 1860-1950," Ph. D. Dissertation, University of Oregon.

Fewkes, WaIter (1924) "Clay Iigurines by Navajo Children," American Antbropologist, (25).

Follansbee, Julia (1978) "Prehistory and History of the Jackson-Klamath Planning Dnit: A Cultural Resources Overview," U.S. Bureau of Land Management, Medford, Cregon.

Gosrke, Mizabeth and Frances Davidson (1975) "Baked Clay Figurines of Marin County," Journal of New World Archeology, (1), 9-23.

Heizer, Robert and Richard Beerdsley (1943) "Mired Clay Flgurines in Central and Northern California," American Antiquity, (9), i99-207.

Heizer, Robert and David Pendergast (1955) "Additional Data on Fired Clay Figurines from Claifornia," American Antiauity, (21), 18i-185.

Mack, Joanne (1977) Personal communication.

viarchiando, Patricia (1965) "A Technological and Statistical Anaiysis of Upper Jmpqua River Artifacts," M.A. Thesis, Jnitersity of Oregon. 
Meighan, Clement (1953) "Ancient Pottery Figurines and their Significance in the Study of Prehistory," Ph. D. Dissertation, Oniversity of California at Berixeley.

Meighan, Clement (1977) Personal commuication.

Neilsen, Susan (1978) "Report of Test Excavation at 35-CU-84," J.S. Bureau of Land Management, Medford, Oregon.

Newman, Thomas (1959) "Final Report on Archeological Salvage: Rmigrant Dam Reservoir," Report of the University of Oregon to the National Park Service.

Sapir, Edward (1907) "Hotes on the TakeIma Indians of Southwestern Oregon," American Anthropologist, (9), 255-275.

Satler, Timothy (1979) "Preliminary Report on Test Excavations at 35-JA-77,".J.S. Bureau of Land Menagement, Medford, Oregon

Shafer, Harry (1975) "Clay Figurines from the Lower Pecos Region, Texas," American Antiquity, (40), 148-157.

Shafer, Farry (1977) "Art and Territoriality in the Lower Pecos," Plains Anthropologist, Pebruary 1977.

Shafer, Harry (1977) Personal communication.

Slocum, Robert and Kenneth Matsen (1968) "Shoto Clay: Figurines and Forms from the Lower Columbia," Oregon Archeological Society, Publication \#4, Binfords \& Mort, Portland, Oregon.

Spier, Leslie (1930) "Blamath Ethnography," University of Califormia Publications in Anerican Archeology and Ethnography (30).

Turpin, Treavell (1979) Personal communication. 